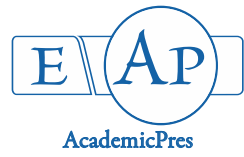

\title{
Arbuscular Mycorrhizal and Dark Septate Endophyte Fungal Association in Cassava (Manihot esculenta Crantz) Varieties, Southern India
}

\author{
Raji MUTHURAJA, Thangavelu MUTHUKUMAR*
}

Bharathiar University, Root and Soil Biology Lab, Coimbatore 641 046, Tamil Nadu, India; tmkum@yahoo.com (*corresponding author)

\begin{abstract}
The study examined the root characteristics, type of arbuscular mycorrhizal (AM) and dark septate endophyte (DSE) fungal associations and their extent of colonization in 13 widely cultivated cassava (Manihot esculenta Crantz) varieties in southern India. Root and associated soil samples of each cassava variety were collected from Salem and Kolli Hills of the Eastern Ghats in south India. In addition, we also investigated the relationship between the extent of colonization of AM, DSE fungal and AM fungal spore communities and soil characteristics for each cassava variety. Roots of all the cassava varieties were colonized by AM fungi and 12 varieties had co-colonization of DSE fungi. The AM morphology in all the cassava varieties was of an intermediate type with intercellular and intracellular linear hyphae and arbusculate coils. In addition, we found high AM colonization rates (73-89\%) but only moderate rates by DSE (22-68\%) fungi. We also found 17 AM fungal spore morphotypes and their abundance varied significantly among cassava varieties. In addition, different physicochemical properties of soils may possibly increase AMF diversity, while different varieties of cassava are commonly associated with differing levels of AM and DSE fungi colonization with soil factors potentially influencing the symbiosis.
\end{abstract}

Keywords: Eastern Ghats; Glomus; intermediate type; rhizosphere soil; Septoglomus

\section{Introduction}

Cassava (Manihot esculenta Crantz) is one of the most important stable tuber crops grown widely in tropical and subtropical regions and does not exist in the wild. In tropics, cassava ranks third among food crops in terms of calories and sixth in terms of annual global production (Burns et al., 2012). About 98 varieties of cassava are cultivated for their tubers that are rich in digestible starch (16-29\%) and vitamin C (Rogers and Appan, 1973). Cassava is a rustic crop that grows well in marginally fertile loamy and sandy soils (Straker et al., 2010). In India, cassava is mainly cultivated in the southern peninsular region and has the highest productivity in Tamil Nadu and parts of Kerala (Sreenivas and Anantharaman, 2005). About 65 - 70\% of cassava varieties cultivated in India are edible. The cassava varieties most preferred by farmers have qualities like high yield, weed suppression capacity and early maturity (Akoroda et al., 1987). Moreover, farmers generally prefer local varieties because of their better performance than the exotic varieties in marginal soils (Brush, 1995). Hence, assessing the different types of variations existing among varieties of cassava could be of greater significance.
The challenging task of increased cassava production stems from its high demand as food and raw material for industrial production of sago, starch, eatables and flour (Carretero et al., 2009; Lebot et al., 2009). Therefore, regular application of synthetic fertilizers is practiced both under irrigated as well as rain-fed conditions to improve growth and yield of cassava in marginal soils (Howler et al., 2013). Indian farmers fertilize cassava with large quantities of synthetic fertilizers indiscriminately at least 4-5 times between 20 and 120 days after planting (Edison et al., 2006). Application of large quantities of synthetic fertilizers affects soil fertility and the environment quality (Abbott and Murphy, 2007). Therefore, it is essential to identify strategies that could either substantially reduce or eliminate synthetic fertilizer use in cassava cultivation. Nevertheless, the qualities of tubers tend to vary among cassava varieties (Herren and Beanett, 1984).

Arbuscular mycorrhizal (AM) fungi are ubiquitous soil fungi colonizing the roots of most crop species (Schüßler et al., 2001). These fungi help plants in their uptake of water, and nutrients such as phosphorus $(\mathrm{P})$ and nitrogen $(\mathrm{N})$ from stressed soils, in exchange for the fixed carbon (Lendenmann et al., 2011). Furthermore, AM fungi also impart resistance in host plants against various biotic and abiotic stresses, improve soil aggregation and biomass and crop yield (Oyetunji and Osonubi, 2007). These types of 
growth and yield responses have been demonstrated for cassava both under controlled and field conditions (Okon et al., 2010; Ceballos et al., 2013). Further, inoculation of AM fungi has been shown to mitigate salt and water stress in cassava (Oyetunji and Osonubi, 2007). All these clearly indicate the importance of AM fungi in sustainable cultivation of cassava (Cardoso and Kuyper, 2006).

The root architecture of tuber crops like cassava are not well investigated like those of cereal crops (Villordon $e t$ al., 2014). The adventitious roots of cassava are distinguished into absorbing roots and storage roots. The absorbing roots acquire water and nutrients from the soil as well as anchor the plant in the soil. In contrast, the storage roots accumulate starch as a reserve in their tissues (Figueiredo $e t$ al., 2015). It is generally believed that root characteristics like the root thickness and the presence and abundance of root hairs determine the mycorrhizal occurrence and dependency in terrestrial plants (Smith and Read, 2008). This view was recently contradicted by Maherali (2014) who showed that root architecture may not be a reliable predictor for mycorrhizal growth response. The dependence of cassava on AM fungi may be moderate to high as evidenced by the large increase in plant growth and yield in response to mycorrhizal inoculation (Straker et al., 2010). Therefore, we intended to analyze if root hair characteristics in cassava had any influence on the extent of root colonization by the soil fungi.

Studies have also shown that varieties of a crop species could also vary in their extent of mycorrhizal colonization (Smith and Smith, 2011). These type of variations in colonization levels have been observed in fruit crops like papaya (Khade and Rodrigues, 2009) and field crops like peanut (Carrenho et al., 2007), nevertheless, such information is not available for any tuber crops. The AM colonization patterns within plant roots are categorized as, Arum - and Paris- or intermediate-type based on the intraradical distribution of the fungal structures (Dickson, 2004). Though, studies have reported AM colonization patterns in roots of different plant species (Dickson et al., 2007) information on AM morphology among varieties of a crop species is largely unknown.

The plant's dependency and benefit from AM association tend to vary with the colonizing AM fungi. Therefore, it is important to understand the diversity of AM fungi associated with a plant species. Some studies have shown that cassava can associate with a wide range of AM fungi (Oyetunji and Osonubi, 2007; Straker et al., 2010; Voko et al., 2013). Studies from Africa and Brazil have assessed the diversity of AM fungi associated with cassava. The results of these studies indicate both low and high diversity of AM fungi associated with cassava (Straker $e t$ al., 2010; Voko et al., 2013). A recent investigation on the effect of $\mathrm{N}$ and potassium $(\mathrm{K})$ fertilization and tillage on AM fungal diversity and root colonization of some cassava varieties in Eastern and Southern Cameroon indicated that root colonization was 35 - $45 \%$ regardless of the variety and farming system (Begoude et al., 2016). Further, AM fungal spore morphotypes belonging to Acaulospora, Gigaspora, and Glomus was found associated with cassava varieties and tillage significantly reduced the AM fungal spore numbers and their diversity (Begoude et al., 2016). Nevertheless, one study from India by Karthigairaj and Kalaiarasu (2015) have reported an AM root colonization range of $39-57 \%$ and the predominance of spore morphotypes belonging to Acaulospora or Gigaspora in the rhizosphere soils of cassava cultivated in semi-arid tropics of Tamilnadu, south India

The dark septate endophyte (DSE) fungi are a group of melanized Ascomycetous fungi characterized by dematiaceous septate hyphae and microsclerotia. These fungi frequently colonize plant roots of different ecosystems (Mandyam and Jumpponen, 2005). The limited information available on the DSE symbiosis is due to a number of issues, including the high taxonomic diversity of these fungi (Newsham, 2011) and strain level host specificity (Reininger et al., 2012). Moreover, experimental studies on the interaction between plants and their rootassociated-fungi revealed that DSE could stimulate plant growth under specific environmental conditions and enhance plant growth tolerance to various biotic and abiotic stresses (Mandyam et al., 2010). Some fungal endophytic interactions have been widely studied due to the general interest in economically important hosts or fungi (Knapp et al., 2012). However, the roles of AM and DSE colonization of plants in tuber crops are poorly understood. The first step in exploiting any type of plant-microbial symbiosis is to understand the incidence and extent of the symbiosis in the intended plant species. Therefore, we primarily focused this study based on four main objectives: (i) to investigate the occurrence and extent of AM and DSE fungal association and AM colonization patterns in different varieties of cassava (ii) to determine the diversity of AM fungi associated with cassava varieties and (iii) to find if root architecture like fine root diameter, root hair number, and root hair length and diameter had any influence on AM and DSE fungal association, and (iv) to assess if any relationship exists between different root architecture, fungal and soil variables.

\section{Materials and Methods}

\section{Studysites}

A total of 39 root and soil samples were collected from 13 varieties of cassava. Of the 13 varieties sampled, 10 were collected during November 2015 from Tapioca Research Stations at Yethapur (Site-A) and Attur (Site-B) in Salem, Tamil Nadu, India. The remaining three varieties of cassava were sampled between December 2015 from Olaiyaru (SiteC) and, Thamaraikulam (Site-D) of Kolli Hills, Tamilnadu, India (Table 1).The percentage of starch content, yield and crop duration of cassava varieties used in the present study are presented in Table $S 1$.

In Salem, the geological information exhibited charnockite, pyroxene granulite and banded maganetite quartzite and the soils composed of red calcareous and black soils (Subramanian and Selvan 2001). The average annual rainfall is about $763.5 \mathrm{~mm}$, which is almost evenly distributed over both southwest $(314.03 \mathrm{~mm})$ and northeast $(333.25 \mathrm{~mm})$ monsoons (Duran 2014). The mean annual maximum and minimum temperatures are $34.1{ }^{\circ} \mathrm{C}$ and $22.9^{\circ} \mathrm{C}$ respectively (IMD 2013). In Kolli hills, the geology is composed of charnockites associated with 
156

gneisses and metamorphic rocks and a thin layer of ferruginous sandy soil (Legris and Meher-Homji, 1984). The mean annual temperature is $24.7^{\circ} \mathrm{C}$ and the mean minimum temperature is $15.7^{\circ} \mathrm{C}$. The rainfall is seasonal with $500 \mathrm{~mm}$ falling during southwest monsoon and 300 $\mathrm{mm}$ falling during the northeast monsoon (Legris and Meher-Homji, 1984). Plants of all the cassava varieties were propagated through stem cuttings. The crop was fertilized with $45 \mathrm{~kg} / \mathrm{ha}$ of $\mathrm{N}$ (urea), $40 \mathrm{~kg} / \mathrm{ha}$ of $\mathrm{P}\left(\mathrm{P}_{2} \mathrm{O}_{5}\right)$, and 65 $\mathrm{kg} / \mathrm{ha} \mathrm{K}\left(\mathrm{K}_{2} \mathrm{O}\right)$ during land preparation and the fields were regularly hand weeded. The plants sampled were almost in the same stage of development.

Sampling, assessing root morphology and processing roots for fungal colonization

Fine adventitious roots were collected randomly from three individual plants for each cassava variety. The collected roots were washed free of adhering soil and organic debris, and stored in FAA (formaldehyde/acetic acid/70\% ethanol, 5V:5V:90V) until processing.

For assessment of root characteristics, approximately 15 , 1-mm-long, root bits were mounted in water on a microscope slide and observed through Olympus BX51 compound microscope fitted with a calibrated ocular scale at ( $\times 50-100)$. Root diameter and the number, length, and width of root hairs were measured for each cassava varieties according to Ma et al. (2001).

The roots were processed for assessing fungal colonization by washing the roots free of FAA, cutting into $1-\mathrm{cm}$ bits and cleared in $10 \% \mathrm{KOH}\left(90{ }^{\circ} \mathrm{C}\right.$ for $\left.1 \mathrm{~h}\right)$. The cleared roots were acidified $(5 \mathrm{~N} \mathrm{HCl})$, and stained with $0.05 \%$ trypan blue (Koske and Gemma, 1989), overnight. The stained root segments were mounted on clean microscopic slides in a mixture of glycerol and lactic acid $(1: 1, v / v)$. The roots were gently squashed and examined with an Olympus BX51 compound microscope $(\times 400)$ for the presence of AM and DSE fungal structures. The percentage of root length colonized by AM and DSE fungi was determined by the magnified intersection method (McGonigle et al., 1990). In addition to total colonization, the number of intersections containing different AM and DSE fungal structures was also noted. Only roots containing arbuscules and/or arbusculate coils were considered to be AM. The presences of hyaline/melanized hyphae and microsclerotia or moniliform cells characterized DSE fungi (Peterson et al., 2008).

The AM colonization patterns were identified based on the inter- or intracellular distribution of AM fungal structures (Dickson, 2004). When the parallel running hyphae were intra-cellular or hyphal coils were present, the colonization was considered as intermediate type. Images of root colonization and fungal structures were captured with a Prog Res[R] C3 digital camera attached to a BX51 Olympus compound microscope.

\section{Collection and processing of the soil samples}

About $1 \mathrm{~kg}$ of soil attached and adjacent to roots was collected up to a depth of $0-20 \mathrm{~cm}$. The soil samples were air-dried in shade, packed in polythene bags and stored at 4 ${ }^{\circ} \mathrm{C}$. One-half of the soil samples collected was used for analysis of soil chemistry and the other half of the soil was used for extraction and enumeration of AM fungal spores. The $\mathrm{pH}$ and electrical conductivity (EC) of the soil samples were determined electrometrically using respective digital electronic meters (ELICO, India) in a 1:2.5 (soil: water v:v) suspension. The total $\mathrm{N}$ and available $\mathrm{P}$ were determined according to Jackson (1971) and exchangeable K was determined after extraction with neutral ammonium acetate (Jackson, 1971). In addition, iron (Fe), manganese $(\mathrm{Mn})$, zinc $(\mathrm{Zn})$ and copper $(\mathrm{Cu})$ were determined according to diethylenetriaminepentaceticacidtriethanolamine (DTPA-TEA) extraction method (Lindsay and Norvell, 1978).

\section{Isolation, enumeration, and identification of AM fungal} spores

The soil samples were screened for the presence of AM fungal spores according to Muthukumar and Udaiyan (2000). An average of the three subsamples was taken and expressed as the number of AM fungal spores per gram soil sample. All intact AM fungal spores were counted and identified based on spore morphology and subcellular characters and compared to the original descriptions available at Schusslers lab web page (www.Irzmuenchen.de/-schuessler/amphylo/amphylo_species.html) and the culture database established by INVAM (http://www.invam. caf.wvu.edu). The nomenclature for AM fungi is as suggested by Schussler and Walker (2010).

\section{Assessment of the AM fungal communities}

We evaluated community structure and diversity of AM fungal spores by measuring ecological parameters such as species richness, abundance, frequency, relative abundance Shannon-Wiener index, Simpson index and evenness (Magurran, 2004). Species richness $(S)=$ mean number of AM fungal species associated with a cassava variety. Abundance $(\mathrm{A})=$ number of AM fungal spores recorded from each variety. Relative abundance $(\%)=$ abundance of each spore morphotype /total abundance of all the spores $\times$ 100. Frequency $=$ No. of a spore morphotype in a variety/ Total number of occurrence of spore species in all varieties $\times 100$. We calculated three diversity indices: ShannonWiener index $\left(\mathrm{H}^{\prime}\right)$ was calculated using the formula $\mathrm{H}^{\prime}=$ $S P_{i} \ln P_{i}$, where $\mathrm{P}_{i}=n i / \mathrm{N}, n_{i}$ is the spore numbers of a species, and $\mathrm{N}$ is the total number of identified spores in a sample. Simpson's index (D) was measured as D $=\mathrm{S}[\mathrm{ni}(\mathrm{ni}$ $1) / N(N-1)]$, where $n i$ is the spore numbers of an AM fungal species and $N$ is the total number of identified AM fungal spores in a sample (Magurran, 2004). Species evenness (E) was calculated as $\mathrm{E}=\mathrm{H}^{\prime} / \mathrm{H}^{\prime}{ }_{\max }$, where $\mathrm{H}^{\prime}$ is the Shannon-Wiener index and $\mathrm{H}_{\text {max }}$ is $\mathrm{In} S$ (Magurran, 2004).

\section{Statistical analysis}

We examined the significance of the differences in soil, $\mathrm{AM}$ and DSE fungal variables between the sites and varieties using Analysis of Variance (ANOVA). Data on fungal colonization were arcsine transformed and spore numbers were log-transformed to achieve normalization prior to statistical analysis. Mean separations were performed using Duncan's multiple range Test $(\mathrm{P}<0.05)$. 
The relationship between the frequency of occurrence and relative abundance of AM fungal spores was analyzed using regression analysis. Multiple regression (stepwise) analysis was used to identify the soil factors that influenced AM fungal communities. Pearson's correlation coefficient $(\mathrm{r})$ was used to find the overall relationship between soil, AM and DSE fungal variables. We also used principal component analysis (PCA) to correlate between the AM fungal spore species and soil characteristics among cassava varieties to examine the variable relationships. The cassava varieties in rhizosphere soil and AM fungal spore species were tested to calculate the percentage of variance accounted for each component. All statistical analysis was performed by SPSS version 16 and Past 3.1.version software (Hammer et al., 2001).

\section{Results}

\section{Soil characteristics}

The soils were sandy clay loam soil or clay loam and the soil chemistry significantly varied for the cassava varieties (Table 1, Table S5). Soil pH $\left(\mathrm{F}_{12,38}=4.47\right)$ and $\mathrm{EC}\left(\mathrm{F}_{12}\right.$ $\left.{ }_{38}=425.05\right)$ significantly $(\mathrm{p}<0.001)$ varied for cassava cultivars. All the soils were slightly acidic with the $\mathrm{pH}$ ranging from 6.07 (Sree Rekha) to 6.50 Rasi-20. The EC significantly varied among the varieties and ranged between 0.133 (Kerala rose) and 0.600 (Sree Athulya) $\mathrm{dSm}^{-1}$.
Macronutrients like the total $\mathrm{N} \quad\left(\mathrm{F}_{12,38}=540.12\right)$, available $\mathrm{P} \quad\left(\mathrm{F}_{12,38}=48.20\right)$ and exchangeable $\mathrm{K} \quad\left(\mathrm{F}_{12}\right.$, $\left.{ }_{38}=250.30\right)$ in the soil significantly $(\mathrm{p}<0.001)$ varied with cultivars. The total $\mathrm{N}$, available $\mathrm{P}$ and exchangeable $\mathrm{K}$ ranged from 54.33 (CO-1) to 87.33 (Sree Rekha) $\mathrm{mg} \mathrm{kg}^{-1}$, 4.50 (CO-1) to 6.07 (CO-3) mg kg ${ }^{-1}$ and 145.33 (Kerala rose and $\mathrm{H}-165$ ) to 245.33 (Mulluvadi-1) $\mathrm{mg} \mathrm{kg}^{-1}$ respectively.

Similarly, the micronutrient concentrations in the soils significantly $(p<0.001)$ varied with cultivars and ranged from 4.10 (Rasi - 20) to 5.63 (Mulluvadi-1) $\mathrm{mg} \mathrm{kg}^{-1}$ for $\mathrm{Fe}$ $\left(F_{12,38}=33.86\right), 2.33$ (CO-3) to 3.47 (Sree Athulya) $\mathrm{mg} \mathrm{kg}^{-}$ ${ }^{1}$ for $\mathrm{Mg}\left(\mathrm{F}_{12,38}=56.7\right), 0.85$ (Sri Jaya) to $1.26(\mathrm{CO}-3) \mathrm{mg} \mathrm{kg}^{-}$ ${ }^{1}$ for $\mathrm{Zn}\left(\mathrm{F}_{12,38}=5.69\right)$ and 1.27 (Yethapur-1) to 1.62 (Kerala rose, Sri Jaya) $\mathrm{mg} \mathrm{kg}^{-1}$ for $\mathrm{Cu}\left(\mathrm{F}_{12,38}=14.21\right)$.

\section{Extent of root characteristics}

The diameter of the roots, and the number, length and width of root hairs varied significantly $(\mathrm{p}<0.01)$ among the cassava varieties (Fig. 1). The root diameter (RD) ranged from $532.79 \mu \mathrm{m}$ [CO (T.P)] to $1533.14 \mu \mathrm{m}$ (Sri Jaya). The root hair number (RHN) per $\mathrm{mm}$ of the root ranged from 40.67 [CO (T.P)] to 200.67 (Sri Vijaya), root hair length (RHL) ranged from $53.33 \mu \mathrm{m}$ (Rasi-CO) to $113.33 \mu \mathrm{m}$ (Sri Vijaya), and the root hair width (RHW) ranged between $12.00 \mu \mathrm{m}(\mathrm{CO}-3)$ and $22.67 \mu \mathrm{m}$ (Rasi-20) (Fig. 1, Table S2).

Table 1. Study sites showed latitude and longitude, altitude $(\mathrm{m})$, soil type and cassava varieties at different locations

\begin{tabular}{ccccc}
\hline & \multicolumn{2}{c}{ Salem } & \multicolumn{2}{c}{ Kolli hills } \\
\cline { 2 - 5 } & Yethapur-TRS & Attur & Olaiyaru & Thamaraikulam \\
\hline Latitude N & $11^{\circ} 40.012^{\prime}$ & $11^{\circ} 35.576$ & $11^{\circ} 16.846$ & $11^{\circ} 16.907^{\prime}$ \\
Longitude E & $78^{\circ} 28.598$ & $78^{\circ} 35.519$ & $78^{\circ} 23.486$ & $78^{\circ} 23.620^{\prime}$ \\
Altitude (m) & 282 & 212 & 986.7 & 974.1 \\
Soil type & Sandy clay loam & Sandy clay loam & Sandy loam & Clay loam \\
& Yethapur - 1,CO (T.P), Sri & & & H226 \\
Cassava varieties & VijayaCO-3, Kerala rose, Sree & Mulluvadi - 1 & H-165, CO1 & \\
& Athulya, Rasi - 20, Sri Jaya, Sree & & & \\
\hline
\end{tabular}

Table 2. Arbuscular mycorrhizal (AM) and dark septate endophyte (DSE) fungal association and AM morphology of different varieties of cassava

\begin{tabular}{|c|c|c|c|}
\hline Cassava variety & Site & Fungal association & AM morphology type \\
\hline Yethapur- 1 & $\mathrm{~A}$ & AM, DSE & $\mathrm{I}^{4}$ \\
\hline $\mathrm{CO}$ (T.P) 4 & & AM, DSE & $\mathrm{I}^{4}$ \\
\hline Sri Vijaya & & AM, DSE & $\mathrm{I}^{4}$ \\
\hline $\mathrm{CO}-3$ & & AM, DSE & $\mathrm{I}^{4}$ \\
\hline Kerala rose & & AM, DSE & $\mathrm{I}^{4}$ \\
\hline Sree Athulya & & AM, DSE & $\mathrm{I}^{4}$ \\
\hline Rasi- 20 & & AM, DSE & $\mathrm{I}^{4}$ \\
\hline Sri Jaya & & $\mathrm{AM}$ & $\mathrm{I}^{4}$ \\
\hline Sree Rekha & & AM, DSE & $\mathrm{I}^{4}$ \\
\hline Mulluvadi - 1 & B & AM, DSE & $\mathrm{I}^{4}$ \\
\hline $\mathrm{H}-165$ & $\mathrm{C}$ & AM, DSE & $\mathrm{I}^{4}$ \\
\hline $\mathrm{CO} 1$ & & AM, DSE & $\mathrm{I}^{4}$ \\
\hline $\mathrm{H} 226$ & $\mathrm{D}$ & AM, DSE & $\mathrm{I}^{4}$ \\
\hline
\end{tabular}

I, Intermediate-type

Site-A, Yethapur (TRS), Site- B, Attur Site- C,Olaiyaru, Site- D Thamaraikulam 

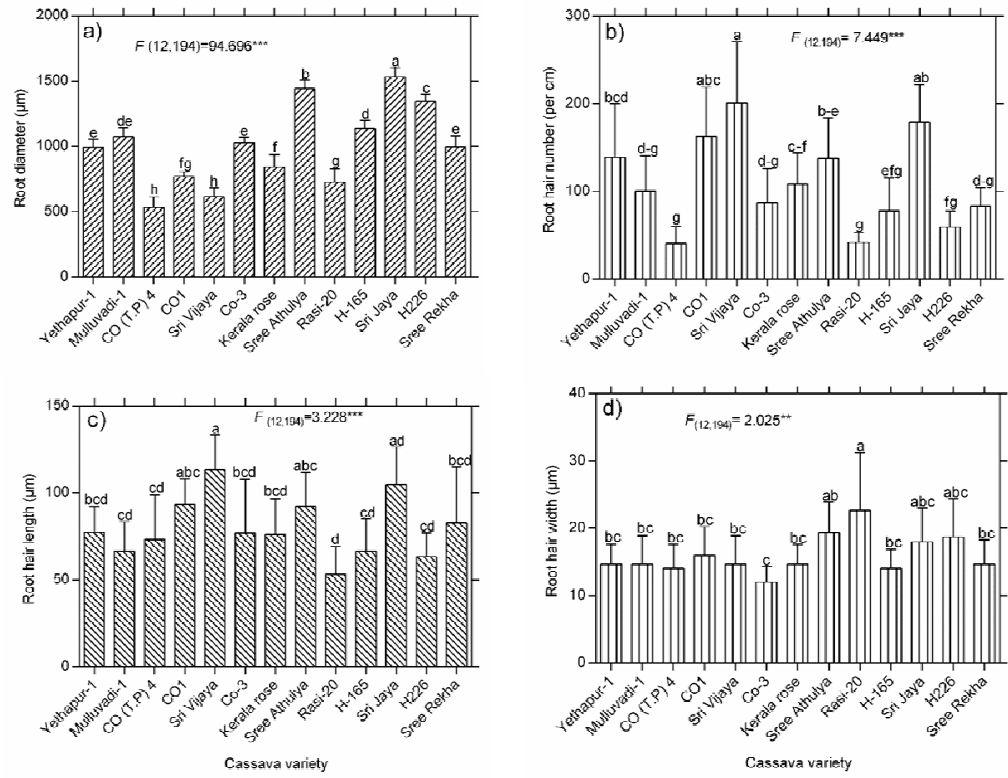

Fig. 1. Root characteristics of different variety of cassava plants (a-d). Data's are means \pm SE of three replicates. The letter(s) 'a, 'b', 'c', and'd' indicate that the values are statistically different at $\mathrm{p}<0.05$ (ANOVA and Duncan's Multiple Range Test).

\section{AM fungalmorphology}

Roots of all the cassava varieties were colonized by AM fungi and intermediate type AM morphology of subtype-4 ( $\left.\mathrm{I}_{4}\right)$ occurred in all the cassava varieties (Table 2). The $\mathrm{I}_{4}$ colonization morphology was characterized by intercellular hyphae and intracellular hyphal/arbusculate coils (Fig. 2). Typical Arum- or Paris-type AM morphology was not observed in any of the root samples examined.

\section{Extent of AM fungal colonization}

All the AM fungal variables examined differed significantly among the cassava varieties (Fig. 3, Tbale S3). The percentage of total root length colonization (\%RLTC) ranged from 73\% (Sree Athulya) to 88\% (Sri Vijaya) (Table S3). The percentage root length with inter- or intracellular hyphae (\%RLH) ranged between 9\% (H-165) and 32\% (H226). Similarly, the percentage of root length with arbuscules (\% RLA) ranged from $5 \%$ (Sri Jaya) to $21 \%$
(Yethapur-1) and the percentage root length vesicles (\%RLV) ranged from $1 \%$ (Rasi - 20) to $26 \%$ (Sri Jaya). Vesicles were absent in the roots of Co (T.P) 4, CO1, Kerala rose and $\mathrm{H} 226$ cassava varieties.

\section{Extent of DSE fungal colonization}

Dark septate endophyte fungal structures were observed in roots of all the cassava varieties except Sri Jaya. The DSE fungal colonization was characterized by hyaline or melanized hyphae that were regularly septate with moniliform cells and/or microsclerotia. The extent of root length with different DSE fungal structures differed significantly $(p<0.01)$ among the different varieties of cassava (Fig. 4). The extent of total root length DSE fungal colonization ranged between 13\% (Kerala rose) and 67\% (H-165 and Sri Vijaya) (Table S4). The percentage of root length with DSE fungal hyphae (\% RLDH) ranged from $2 \%(\mathrm{CO}-3)$ to $45 \%$ (Mulluvadi- 1 ).

Table 3. Multiple regression (stepwise) analysis of the effects of soil factors on spore species richness, density, Shannon diversity, Simpson and evenness among examined varieties

\begin{tabular}{|c|c|c|c|}
\hline AM fungal parameter $(\mathrm{Y})$ & Soil nutrient variables $(\mathrm{X})$ & Equation $^{*}$ & $\mathrm{R}^{2}$ \\
\hline Species richness & $\mathrm{EC}, \mathrm{pH}, \mathrm{N}, \mathrm{P}, \mathrm{K}$ & $\mathrm{Y}=0.673-0.856 \mathrm{EC}-0.995 \mathrm{pH}+0.022 \mathrm{~N}+1.098 \mathrm{P}+0.524 \mathrm{~K}$ & $0.457^{\mathrm{ns}}$ \\
\hline Spore abundance & $\mathrm{EC}, \mathrm{pH}, \mathrm{N}, \mathrm{P}, \mathrm{K}$ & $\mathrm{y}=-0.443-0.721 \mathrm{EC}+0.132 \mathrm{pH}+0.864 \mathrm{~N}+1.113 \mathrm{P}+0.360 \mathrm{~K}$ & $0.466^{\mathrm{ns}}$ \\
\hline \multirow[t]{4}{*}{ Shannon index } & $\mathrm{EC}, \mathrm{pH}, \mathrm{N}, \mathrm{P}, \mathrm{K}$ & $\mathrm{Y}=1.075-1.186 \mathrm{EC}-1.357 \mathrm{pH}+0.213 \mathrm{NK}+1.373 \mathrm{P}+0.512 \mathrm{~K}$ & 0.614 \\
\hline & EC,pH, & $\mathrm{Y}=3.078-1.28 \mathrm{EC}-2.567 \mathrm{pH}$ & $0.447^{\circ}$ \\
\hline & $\mathrm{pH}, \mathrm{P}$ & $\mathrm{Y}=1.836-2.073 \mathrm{pH}+1.689 \mathrm{P}$ & $0.499^{\circ}$ \\
\hline & $\mathrm{EC}, \mathrm{pH}, \mathrm{P}$ & $\mathrm{Y}=1.994-1.323 \mathrm{EC}-2.196 \mathrm{pH}+1.695 \mathrm{P}$ & $0.58^{*}$ \\
\hline \multirow[t]{4}{*}{ Simpson index } & $\mathrm{EC}, \mathrm{pH}, \mathrm{N}, \mathrm{P}, \mathrm{K}$ & $\mathrm{Y}=1.927-1.662 \mathrm{pH}-1.479 \mathrm{EC}+0.098 \mathrm{~N}+1.428 \mathrm{P}+0.436 \mathrm{~K}$ & $0.655^{\mathrm{ns}}$ \\
\hline & $\mathrm{pH}, \mathrm{P}$ & $\mathrm{Y}=2.689-2.249 \mathrm{pH}+1.729 \mathrm{P}$ & $0.528^{*}$ \\
\hline & $\mathrm{EC}, \mathrm{pH}, \mathrm{P}$ & $\mathrm{Y}=3.023-1.660 \mathrm{EC}-2.497 \mathrm{pH}+1.804 \mathrm{P}$ & $0.638^{*}$ \\
\hline & $\mathrm{pH}, \mathrm{K}$ & $\mathrm{Y}=4.290-1.366 \mathrm{pH}-3.006 \mathrm{~K}$ & $0.485^{\circ}$ \\
\hline \multirow[t]{2}{*}{ Evenness } & $\mathrm{EC}, \mathrm{pH}, \mathrm{N}, \mathrm{P}, \mathrm{K}$ & $\mathrm{y}=4.619-0.072 \mathrm{EC}-2.126 \mathrm{pH}-1.714 \mathrm{~N}-2.360 \mathrm{~K}$ & $0.623^{\mathrm{ns}}$ \\
\hline & $\mathrm{pH}, \mathrm{K}$ & $\mathrm{Y}=4.290-1.366 \mathrm{pH}-3.006 \mathrm{~K}$ & $0.485^{\circ}$ \\
\hline
\end{tabular}




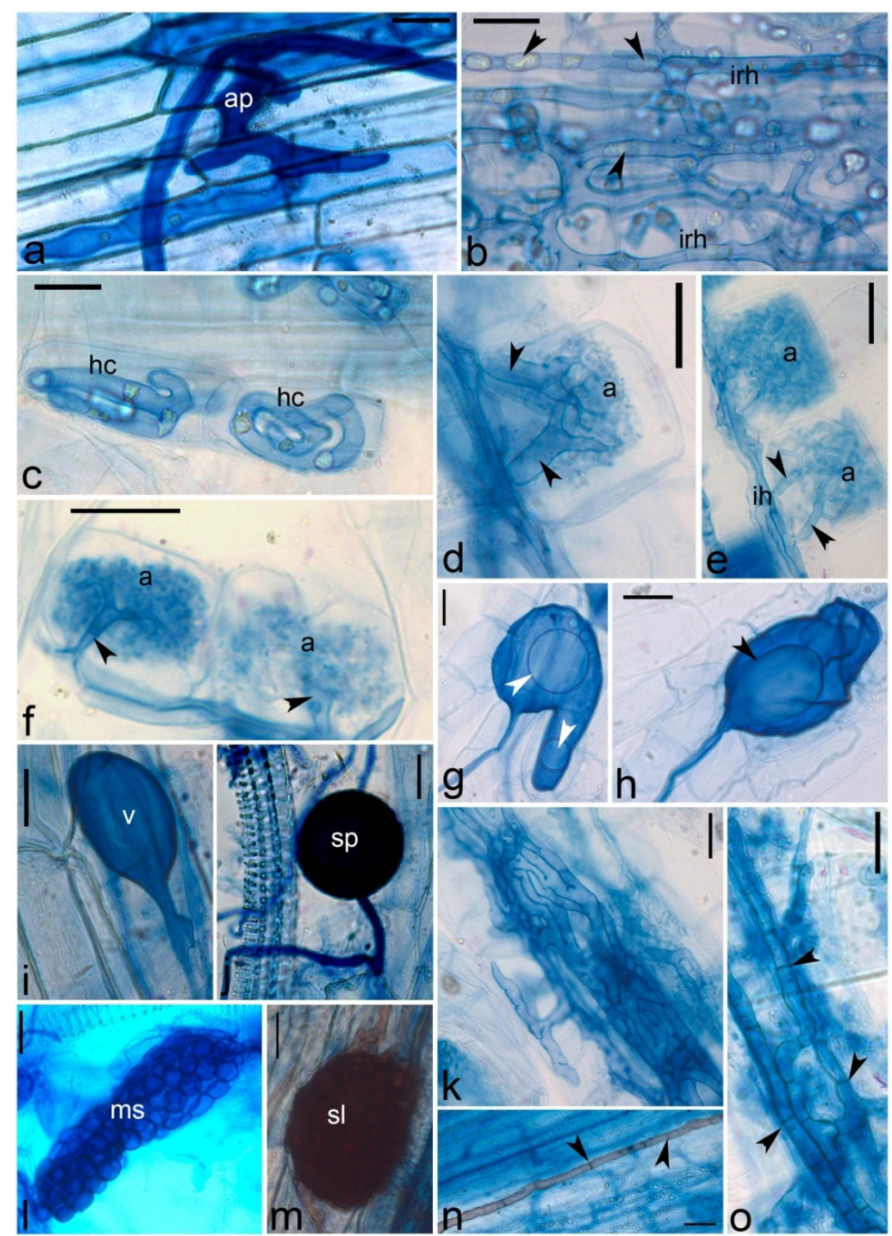

Fig. 2. Arbuscular mycorrhizal (AM) (a-j) and dark septate endophyte (DSE) (k-o) fungal associations in cassava varieties cultivated in Southern India. (a) Appressorium (ap) and extraradical hyphae in Mulluvadi, (b) Intracellular hyphae (irh) and oil droplets (arrow heads) in CO-3, (c) Hyphal coils (hc) in cortical cells of H-165, (d) Arbuscular trunk (arrow heads) and arbuscule (a) in H226, (e) intercellular hyphae (ih), arbuscular trunk (arrow head) and arbuscule (a) in CO1, (f) Arbuscular trunks (arrow heads) and arbuscules (a) in Sri Jaya (g-h) Vesicle and oil droplets (arrow head) in H226, (i) Vesicle in Rasi - 20, (j) Spore (sp) attached to root in CO (T.P)4, (k) Intracellular septate hyphae in Sree Rekha, (l) microsclerotia (ms) in CO-3, (m) Sclerotium (sl) in Yethapur-1,(n) melanized septate hyphae (arrow heads) in Mulluvadi - 1, (o) H- shaped dark septate hyphal branching (arrow head) in Yethapur -1 . Scale bars $=25 \mu \mathrm{m}$.

The percentage root length with moniliform hyphae (\% RLMO) ranged between 2\% (Yethapur-1) and 4\% (Mulluvadi-1) and the percentage of root length with microsclerotia (\% RLMI) ranged between $28 \%(\mathrm{H}-165)$ to $45 \%$ (CO-3) (Fig. 4). Moniliform hyphae were absent in roots of the majority of the cassava varieties.

AM fungal spore richness, abundance, and diversity in cassava varieties

AM fungal spore richness, abundance and diversity indices of Simpson and Shannon varied significantly among cassava varieties (Table S6). In contrast, evenness was almost similar for all the cassava varieties. The AM fungal species richness was significantly correlated with spore abundance among cassava varieties (Fig. S1a). Mean species richness and spore abundance ranged from 4 to 10 and 19.67 to 76.33 respectively. A total of 17 AM fungal spore morphotypes belonging to Acaulospora (4), Gigaspora (2),
Glomus (8), Sclerocystis (1), Scutellospora (1) and Septoglomus (1) were isolated from the soils of different varieties of cassava (Fig. 5). The mean AM fungal species richness across cassava varieties was $6.62 \pm 0.63$. The AM fungal species richness was highest for Yathapur-1 and H226 (10 species) and lowest for CO1, Sree Atulya, Rasi20 (4 species each) (Table S2). The overall mean spore abundance across varieties was $100.16 \pm 14.9$ spores per 100 g soil. The spore abundance was highest for H226 (229 spores per $100 \mathrm{~g}$ soil) and lowest for in CO1 (59 spores per $100 \mathrm{~g}$ soil). Moreover, the mean value of Simpson and Shannon indices ranged from 0.69 to 0.88 and 1.26 to 2.20 respectively. Mean evenness values ranged from 0.83 to 0.96 among the cassava varieties.

\section{Relative abundance and frequency of AM fungal spores}

The results also showed that the frequency and relative abundance of AM fungal spores were significantly related to 
160

each other $\left(\mathrm{R}^{2}=0.962, \mathrm{p}<0.0001\right.$; Fig. S1b). Spores of Acaulospora scrobiculata and Gigaspora gigantea was most frequent among the different AM spore morphotypes isolated from different cassava varieties. In contrast, spores of Septoglomus viscosum were rare. The calculated relative abundance value was minimum for $S$. viscosum (0.71) and maximum $A$. scrobiculata (14.03) (Table S7).

\section{Relationship between soil and AM fungal spore variables}

The soil variables $\mathrm{pH}, \mathrm{EC}, \mathrm{N}, \mathrm{P}$, and $\mathrm{K}$ did not significantly influence species richness or abundance of AM fungal spores as revealed by the stepwise multiple regression analysis. Nevertheless, Shannon diversity index was significantly influenced by $\mathrm{EC}, \mathrm{pH}, \mathrm{N}, \mathrm{P}$, and $\mathrm{K}$, whereas Simpson diversity index was positively correlated to EC, $\mathrm{pH}$, and $\mathrm{P}$. In addition, evenness was positively correlated to $\mathrm{pH}$ and $\mathrm{K}$ (Table 3 ).

\section{factors}

Correlation between AM and DSE fungal variables to soil

Potassium was the only soil factor that influenced most of the AM and DSE fungal variables. As soil $\mathrm{K}$ was significantly and positively correlated to RLH, RLV, and RLTC of AM fungi, it was negatively correlated to RLA. A significant negative correlation also existed between RLA and soil N. For DSE fungi, soil $\mathrm{K}$ was correlated significantly and positively to RLMO and negatively to RLMI. As soil P was significantly and positively correlated to RLMI, it was significantly and negatively correlated to RLMO (Table 4).

Soil EC was significantly and positively correlated to RLHC, but this soil variable had a significant negative correlation with RLAC. A significant negative correlation also existed between $\mathrm{pH}$ and $\mathrm{RLH}$. A positive correlation existed between RLA and soil Fe and RLHC and soil Mn. A significant positive correlation also existed between soil $\mathrm{Mn}$ and RLDH, and soil Zn and RLMI (Table 4).

\section{Principal component analysis}

The principal component analysis revealed an F1 Eigen value of $23.14 \%$ and F2 Eigen value of $18.26 \%$ resulting in a total variation of $41.40 \%$. Arbuscular mycorrhizal spores of four species were grouped on the two different sides and the remaining spore morphotypes were separated from one another (Fig. 7). Among the thirteen varieties of cassava, three different clusters emerged based on the mycorrhizal and DSE fungal characteristics in PCA (Fig. S2a).

Principal components analysis was also used to examine the influence of soil characteristics on the distribution of AM spore morphotypes in different cassava varieties (Fig. 7). The first two dimensions of the PCA explained $42.33 \%$ of the total variation of which component 1 accounted for $24.22 \%$ and component 2 accounted for $18.11 \%$ of total variations suggesting that the cassava rhizosphere soils significantly influenced the distribution of AM fungal spore morphotypes in the cassava root zones.
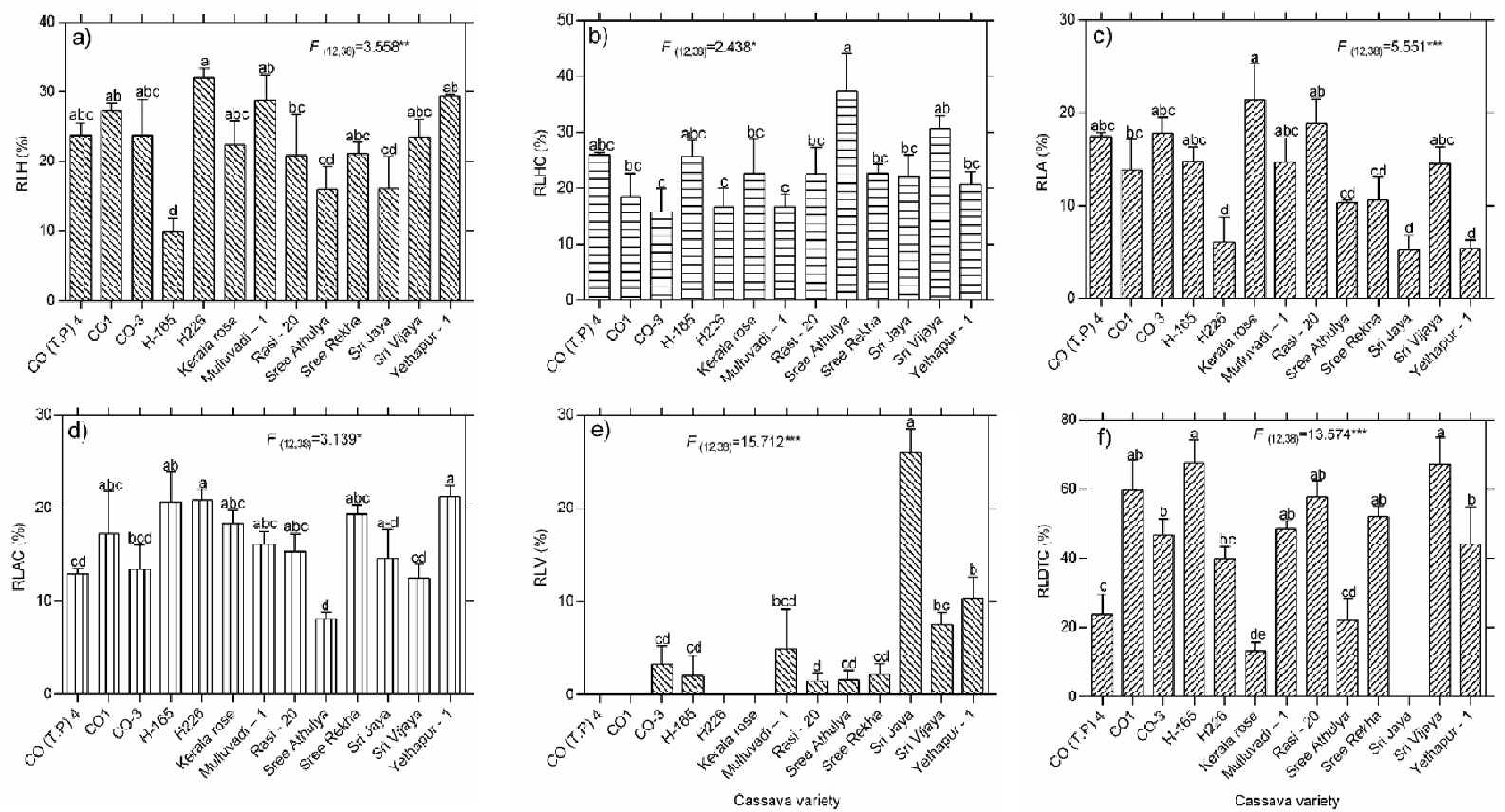

Fig. 3. The extent of arbuscular mycorrhizal (AM) fungal colonization characteristics variation among different varieties of cassava (a-f). Data's are means \pm SE of three replicates. The letter(s) 'a', 'b', 'c', and 'd' indicate that the values are statisticallydifferent at $\mathrm{p}<0.05$ (ANOVA and Duncan's Multiple Range Test). RLH, RLHC, RLA, RLAC, RLV, RLTC - Root length with hyphae, hyphal coils, arbuscules, arbusculate coils, vesicles and total colonization respectively. 
Table 4. Pearson's correlation coefficients between various arbuscular mycorrhizal (AM) fungi, and dark septate fungal endophyte (DSE) and soil variables $(\mathrm{SV})$

\begin{tabular}{|c|c|c|c|c|c|c|c|c|c|c|}
\hline \multirow{2}{*}{ Soil variables } & \multicolumn{6}{|c|}{$\mathrm{AM}^{*}$} & \multicolumn{4}{|c|}{$\operatorname{DSE}^{\# \#}$} \\
\hline & RLH & RLHC & RLA & RLAC & RLV & RLTC & RLDH & RLMO & RLMI & RLDTC \\
\hline $\mathrm{EC}$ & -0.244 & $0.506^{\circ}$ & -0.122 & $-0.500^{*}$ & -0.097 & -0.231 & 0.002 & -0.120 & -0.200 & -0.210 \\
\hline $\mathrm{pH}$ & $-0.321^{*}$ & 0.130 & 0.235 & -0.117 & 0.139 & 0.067 & 0.002 & -0.096 & -0.228 & -0.115 \\
\hline $\mathrm{N}$ & 0.167 & 0.068 & $-0.523^{*}$ & 0.177 & 0.200 & 0.135 & -0.022 & -0.228 & 0.272 & 0.121 \\
\hline $\mathrm{P}$ & -0.125 & -0.128 & 0.080 & 0.027 & -0.062 & -0.248 & -0.206 & $-0.506^{\circ}$ & $0.573^{*}$ & 0.225 \\
\hline K & $0.353^{\circ}$ & -0.030 & $-0.488^{*}$ & -0.085 & $0.453^{\prime \prime}$ & $0.327^{\circ}$ & 0.162 & $0.322^{\circ}$ & $-0.461^{*}$ & -0.312 \\
\hline $\mathrm{Fe}$ & -0.008 & 0.104 & $0.343^{\circ}$ & -0.010 & -0.226 & 0.152 & -0.047 & 0.002 & 0.238 & 0.188 \\
\hline $\mathrm{Mn}$ & -0.194 & $0.391^{\circ}$ & -0.052 & -0.098 & -0.199 & -0.081 & 0.396 & 0.044 & -0.192 & 0.143 \\
\hline $\mathrm{Zn}$ & 0.005 & -0.051 & 0.036 & -0.130 & -0.184 & -0.293 & -0.180 & -0.211 & $0.330^{\circ}$ & 0.041 \\
\hline $\mathrm{Cu}$ & -0.020 & 0.066 & 0.033 & -0.059 & 0.264 & 0.305 & -0.178 & -0.026 & -0.251 & -0.309 \\
\hline
\end{tabular}

"RLH, RLHC, RLA, RLAC, RLV, and RLTC; root length with AM fungal linear hyphae, hyphal coils, arbuscules, arbusculate coils, and total colonization respectively. "RLDH, RLMO, RLMI, and RLDTC; root length with DSE fungal hyphae, moniliform cells, microsclerotia, and total colonization respectively. Soil pH; EC, electrical conductivity, nitrogen $(\mathrm{N})$, phosphorus $(\mathrm{P})$ and potassium $(\mathrm{K})$, Iron $(\mathrm{Fe})$, manganese $(\mathrm{Mn})$, copper $(\mathrm{Cu})^{* *}$ significance at $1 \%$ level, ${ }^{*}$ significance at $5 \%$ level
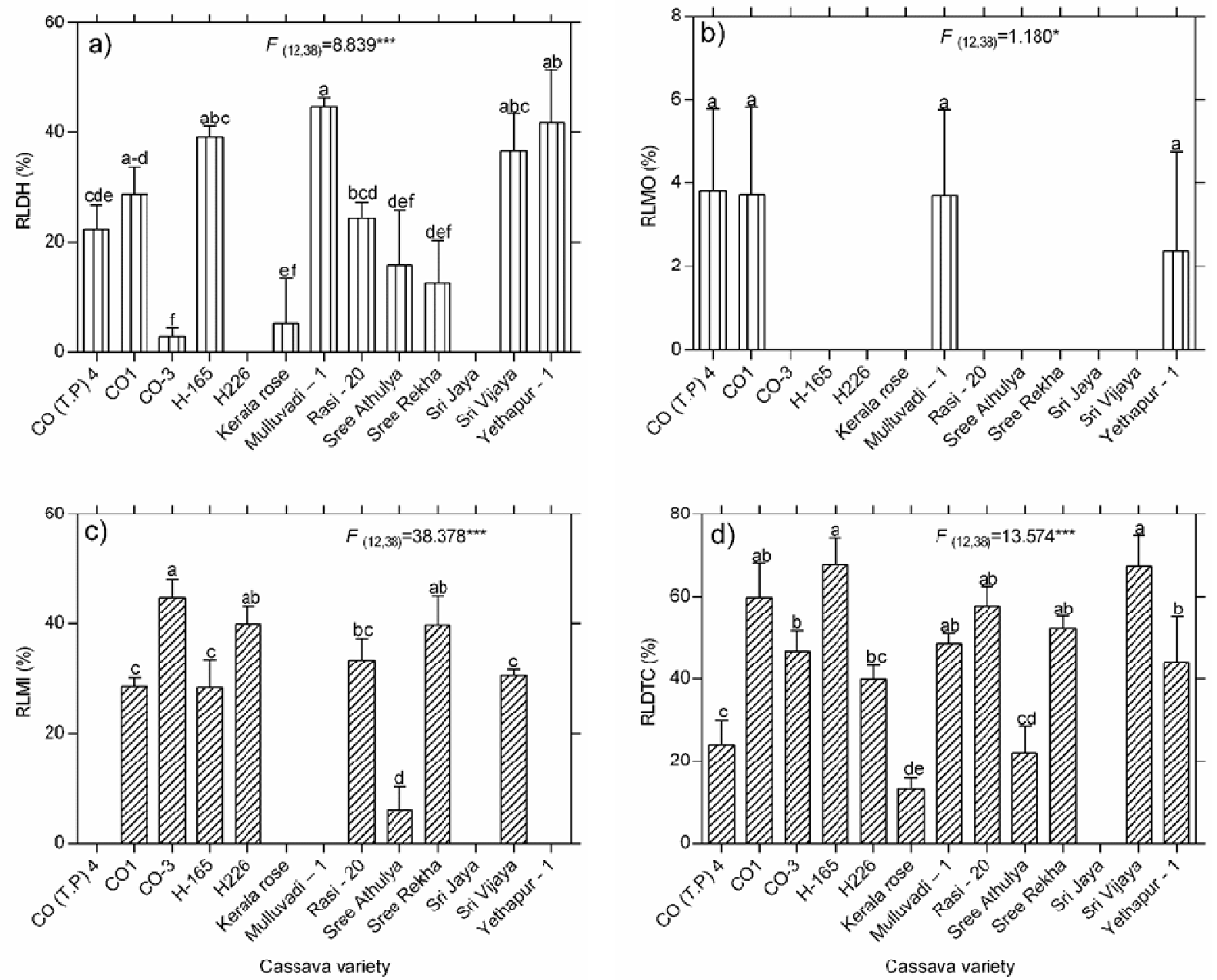

Fig. 4. Extent of dark septate endophytic (DSE) fungal colonization with different varieties of cassava (a-f). Data's are means \pm SE of three replicates. The letter(s) 'a', 'b', 'c', and 'd' indicate that the values are statistically different at $p<0.05$ (ANOVA and Duncan's Multiple Range Test). RLDH, RLMO, RLMI, and RLDTC- Root length with DSE fungal hyphae, moniliform cells, microsclerotia, and total colonization respectively. 
162
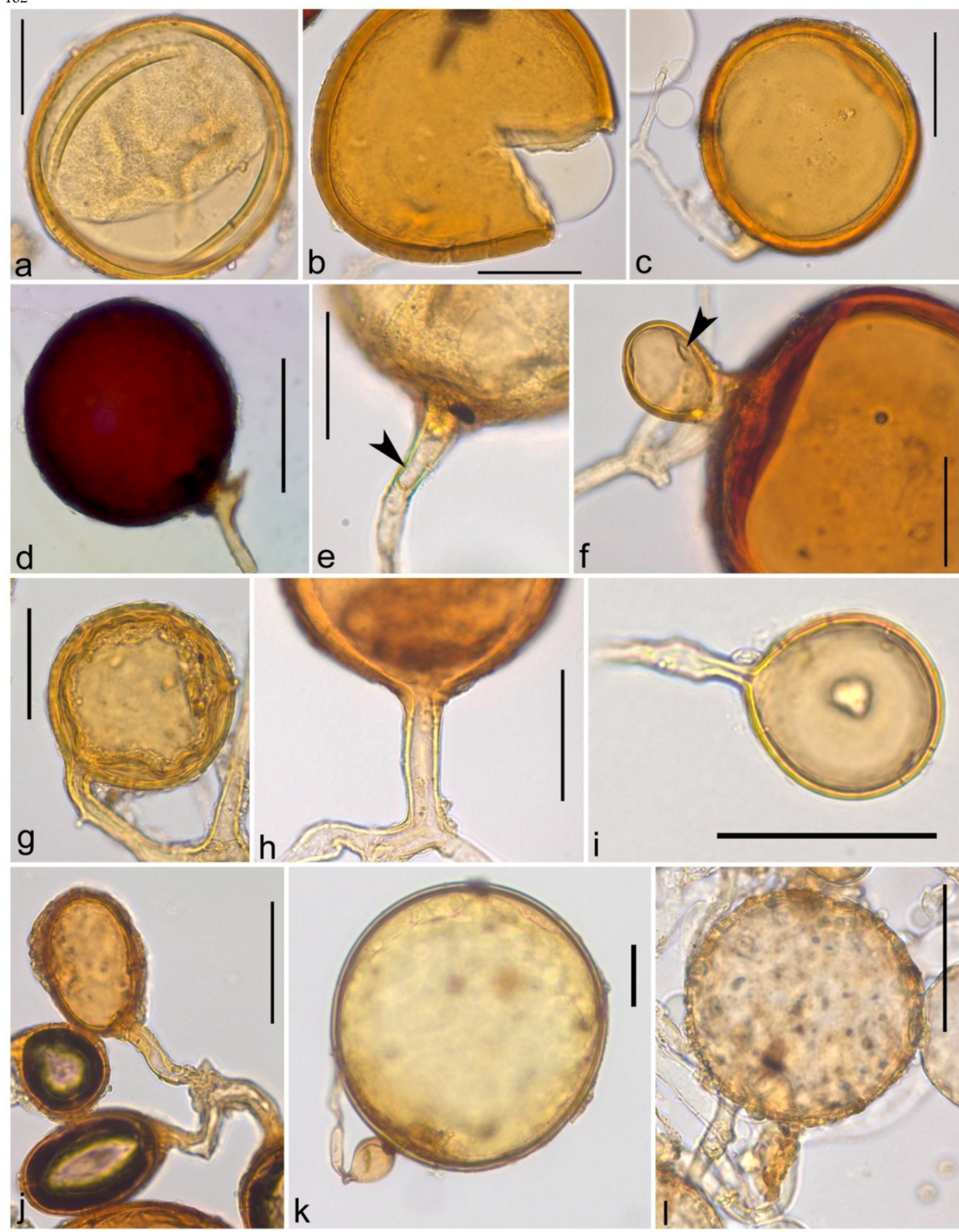

Fig. 5. Spores of Glomeromycota isolated from the rhizosphere of Cassava. (a) Spore of Acaulospora foveata, (b) Fractured spore of Acaulospora mellea, (c) Spore of Claroideoglomus etunicatum, (d) Glomus constrictum (e) Curved septum in the subtending hyphae of Funneliformis mosseae (arrow head) (f) Spore of Glomus hyderabadensis with spore out growth (arrow head), (g) spore of Glomus microcarpum, (h) Glomus monosporum, (i) Glomus microaggregatum, (j) Sclerocystis rubiformis, (k) Spore of Scutellospora calospora, (1) Spores of Septoglomus viscosum. Scale bars $=50 \mu \mathrm{m}$. 


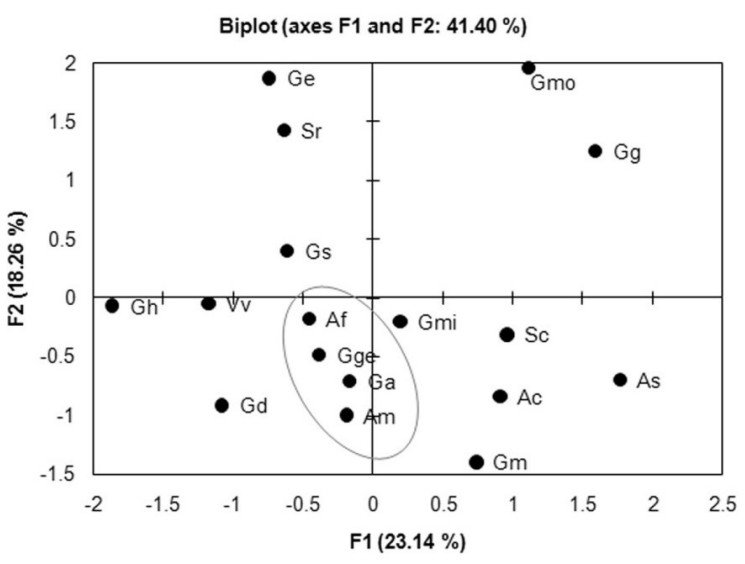

Fig. 6. Cluster analysis of spore species frequency among 13 varieties of cassava. The spore species name are as follows: $\mathrm{Ge}$ Glomus, Gmo- Funneliformis mosseae; Af, Acaulospora foveata; Am, Acaulospora mellea; As, Acaulospora scrobiculata; Ac, Acaulospora sp.; Gge, Claroideoglomus etunicatum; Gd, Gigaspora decipiens; Gg, Gigaspora gigantea; Ga, Glomus aggregatum; Gh, Glomus hyderabadensis; Gm, Glomus macrocarpum; Gmi, Glomus microaggregatum; Sr, Sclerocystis rubiformis; Sc, Scutellospora calospora; Vv, Septoglomus viscosum.

\section{Discussion}

Our results revealed that all the cassava varieties had high levels of AM and moderate levels of DSE fungal colonization. In addition, this is the first report for the presence of DSE fungal association in cassava varieties as confirmed through a wide range of literature survey and to the best of our knowledge. The AM colonization levels observed in the cassava varieties in this study is higher than those previously reported for cassava from south India (Muthukumar and Tamilselvi, 2010; Karthigairaj and Kalaiarasu, 2015) and Africa (Oyetunji and Osonubi, 2007; Begoude et al., 2016). The AM fungal colonization levels observed is similar to studies where cassava was inoculated with AM fungi under controlled conditions (Ceballos et al., 2013). Burns et al. (2012) also reported a wide range of AM fungal colonization levels ranging from $51-93 \%$ in cassava examined from Mozambique. The low nutrient content of the studied soils inspite of regular fertilization might have contributed to the high AM colonization levels in the cassava varieties. This is contrary to the observations of Begoude et al. (2016) who found a reduction in AM fungal colonization in response to high fertilizer application in cassava. As per the nutritional requirement of cassava, Howeler, (2002) classified the soils into very low, low, medium, high and very high. Based on this classification, the $\mathrm{Cu}$ content in the soils of the present study was high; $\mathrm{pH}$, exchangeable $\mathrm{K}$, and $\mathrm{Zn}$ were medium; available $\mathrm{P}$ and $\mathrm{Fe}$ was low and $\mathrm{Mn}$ was very low.

In contrast to the observations of Burns et al. (2012) from Mozambique, the extent of AM colonization showed considerable variation among the cassava varieties. This

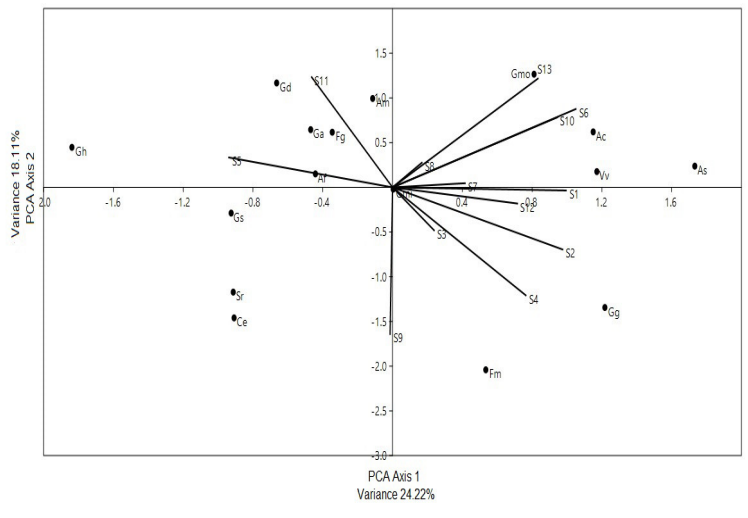

Fig. 7. Principle component analysis (PCA) biplot were assessed on the relationship between cassava varieties and AM fungal spore species are examined. For fungal species, 1 and 0 were used to represent presence and absence of particular in each cassava variety according to frequency of spore isolation.

variation could be attributed to the varying dependency or the differential preference of the cassava varieties on AM fungi. Such variation in the extent of root colonization by AM fungi has been reported for varieties of papaya, apple and peach (Khade and Rodrigues, 2009; Straker et al., 2010). The colonization of roots by AM fungi and the development of fungal structures within roots is the product of an interaction between the host, and the environmental factors. The low incidence of vesicles or their absence in certain cassava cultivars compared to other AM fungal structures could be due to two reasons. First, vesicle formation tends to peak during late stages of plant growth when plants dependence on the fungi declines and secondly if the AM fungal community colonizing the roots is dominated by members belonging to Gigasporales, the frequency of vesicles may be low as these fungi do not form vesicles within plant roots (Smith and Read, 2008).

Though roots of many mycorrhizal crop plants have been examined for AM fungal morphology (Dickson, 2004) there is still many for which the AM morphology is yet to be ascertained. In accordance with a previous study, all the cassava varieties had intermediate type AM morphology (Muthukumar and Tamilselvi, 2010). Further, interestingly, all the cassava varieties also had the same intermediate subtype $\mathrm{I}_{4}$ (Dickson, 2004). Although the factors that determine the AM morphology within roots is not clear, available evidence to indicate that it is an interaction of several factors like root structure, environmental conditions, and fungal species (Dickson et al., 2007).

Root architecture has not been adequately investigated for tuber crops including cassava (Villordon et al., 2014; Khan et al., 2016). Only one previous study has reported the presence of abundant root hairs on fine roots of in vitro raised cassava (Medina et al., 2007). The present study reports the extent of variation in root architecture among the cassava varieties for the first time and clearly shows that root hair characters can vary independently of soil factors. One possible reason for the lack of relationship between soil factors and root architecture in the present study could be 
164

the low levels of soil nutrients insufficient to influence root architecture. In contrast to our anticipation, we failed to find any significant influence of root architecture on the endorhizal fungal variables at least in the cassava varieties studied. This corroborates the observations of Maherali (2014) who indicated that root architecture cannot be a predictor of mycorrhizal colonization or mycorrhizal mediated growth response in plants.

The AM fungal community of cassava was dominated by species of Glomus and Acaulospora similar to other observations in tropical soils (Straker et al., 2010; Voko et al., 2013). Though soil hyphae and mycorrhizal roots of AM fungi can serve as propagules, spores are important propagules in agroecosystems as they could perennate in the absence of living crop roots in the soil until the next cropping season (Smith and Read, 2008). In spite of their importance, AM fungal spore numbers were poorly correlated to the extent of colonization in cassava roots suggesting that AM fungal propagules other than spores could be contributing to mycorrhization (Smith and Read, 2008). Spores of certain AM fungi like $A$. scrobiculata (69\%), G. gigantea (61.5\%), and Glomus macrocarpum $(61.5 \%)$ were more common compared to spores of other species. This indicates that these AM fungal species could adapt to a wide range of soil conditions and host species. On the contrary, spores of Claroideoglomus etunicatum and $S$. viscosum was recorded only in the root zones of $\mathrm{H} 226$ variety suggesting that these species have preferences for specific soil conditions or host species. Nevertheless, this has to be tested through experimental studies.

We also found a significant relationship between relative abundance and frequency of AM fungal spores suggesting sporulation was steady among cassava varieties and was influenced by different soil characteristics under field conditions. In spite of the general perception that monoculture of crops limits AM fungal diversity, the AM fungal species richness recorded in this study is larger than those reported for cassava grown under field conditions (Straker et al., 2010; Voko et al., 2013) and in tropical areas of Benin (Tchabi et al., 2016) and East Africa (Mathimaran et al., 2007). This clearly suggests that crops like cassava can still sustain the high diversity of AM fungi.

All previous studies on cassava have limited their observations only on AM fungi and there is no information on the occurrence of DSE fungi in roots of cassava (Oyetunji and Osonubi, 2007; Straker et al., 2010; Begoude et al., 2016). Our results suggest that DSE fungal colonization like those of AM fungi can vary significantly among cassava varieties. Nevertheless, the proportion of DSE fungal colonization was always lower when compared to AM fungal colonization in all the cassava varieties. Frequent and abundant colonization of plant roots by DSE fungi than AM fungi tends to occur under harsh environmental conditions where the activities of AM fungi are taken over by DSE fungi (Postma et al., 2007). There was no significant interaction between AM fungi and DSE fungi within cassava roots as evidenced by the lack of correlation between these fungal variables. This clearly shows that these fungal types do not influence each other in spite of sharing the same niche within plant roots. As DSE fungi are known to benefit plants under conditions limiting AM fungal activities, it would be interesting to see if such swapping in dependence on fungal types occurs in cassava (Medina-Roldan et al., 2008).

Soil physicochemical properties that play an important role in the determination of AM and DSE fungal colonization levels in plant roots exhibited varied influences such as positive, negative or absence of any demonstrable relationship on fungal variables (Khade and Rodrigues, 2009). In this study, the significant influence of exchangeable soil $\mathrm{K}$ to root length with AM fungal hyphae, vesicles, and total colonization and moniliform cells of DSE fungi suggests that soil $\mathrm{K}$ can strongly affect the colonization of cassava roots by these soil fungi. This is in line with studies where soil $\mathrm{K}$ was shown to influence mycorrhizal symbiosis (Cordones et al., 2014). Previous studies have shown the positive influence of soil $\mathrm{K}$ on AM fungal variables and the prerequisite of certain concentrations of soil K for AM formation (Ouimet et al., 1996). In addition, this study also indicates that even moderate levels of soil $\mathrm{K}$ can influence AM and DSE colonization. Moreover, our results also showed that the low availability of $\mathrm{P}$ and $\mathrm{Fe}$ concentrations in the soil positively influenced the root length with DSE fungal microsclerotia and root length with AM fungal arbuscules, suggesting that under low availability of $\mathrm{P}$ in the soil may favor the formation of AM fungal structures in the roots of cassava varieties. Recently Li et al. (2018), examined whether AM fungi could alleviate abiotic stress caused by low $(\mathrm{P})$ fertilization and deficit irrigation in potato. This resembles the observations of Liu et al. (2016) who showed that low P content could increase AM fungal colonization. Overall, our study also provided new evidence that the interaction between $\mathrm{K}$ and available $\mathrm{P}$ may enhance the dual symbiosis by AM and DSE fungi similar to the one reported for ectomycorrhizae and AM fungi (Garcia and Zimmerman, 2014). In this study, AM and DSE fungal symbiosis were also influenced by soil micronutrients as evidenced by the correlations of $\mathrm{Fe}, \mathrm{Mg}$ and $\mathrm{Zn}$ to $\mathrm{AM}$ fungal hyphae coils, arbuscules and DSE fungal microsclerotia (Willis et al., 2013). In contrast to the observations of Marschner and Dell (1994) Cu concentrations in the soil failed to influence the fungal variables in the cassava varieties. Overall, the study suggested that the $\mathrm{K}$ plays an important role in enhancing colonization of roots by AM and DSE fungi. Further, the influence of soil factors on AM fungal spore diversity in the cassava varieties indicate that the structure of AM fungal communities could determine the activities of these microorganisms in the studied soils (Alguacil et al., 2014).

\section{Conclusions}

Our study results showed that all the cassava varieties had a strong symbiotic association with both AM and DSE fungi. We found for the first time the dominance of intermediate type of AM morphology in different varieties of cassava. In addition, we also found the influence of exchangeable $\mathrm{K}$ and ions such as $\mathrm{Fe}, \mathrm{Mg}$, and $\mathrm{Zn}$ on the extent of AM and DSE fungal colonization in the cassava roots. Moreover, the soil physicochemical properties positively influenced the AM fungal spore diversity which suggests that AM fungal communities are consistent in their structure that may aid to increase growth yields of cassava. Nevertheless, further studies are necessary to evaluate the 
effects of soil nutrient uptake process on AM and DSE fungi colonization in cassava which is essential for sustainable agricultural management practices.

\section{Acknowledgements}

RM gratefully acknowledges the financial support in the form of Rajiv Gandhi National Fellowship from UGC, New Delhi (Grant No.F1-17.1/2016-17/RGNF-2015-17SC-TAM-19396). We also thank the Tapioca Research Stations at Yathapur and Attur, Salem, India for permitting to collect the root and soil samples of cassava examined in the study.

\section{References}

Abbott LK, Murphy DV (2007). Biological soil fertility: A key to sustainable land use in agriculture. Springer Verlag, London, UK.

Akoroda MO, Oyinlola AE, Gebremeskel T (1987). Plantable stem supply system for IITA cassava varieties in Oyo State of Nigeria. Agricultural Systems 24(4):305-317.

Alguacil MM, Torrecillas E, Garcia-Orenes F, Roldán A (2014). Changes in the composition and diversity of AMF communities mediated by management practices in a Mediterranean soil are related with increases in soil biological activity. Soil Biology and Biochemistry 76:3444.

Begoude DAB, Sarr PS, Mpon TLY, Owona DA, Kapeua MN, Araki S (2016). Composition of arbuscular mycorrhizal fungi associated with cassava (Manihot esculenta Crantz) cultivars as influenced by chemical fertilization and tillage in Cameroon. Journal of Applied Biosciences 98:9270-9283.

Brush SB (1995). In situ conservation of landraces in centers of crop diversity. CropScience 35(2):346-354.

Burns AE, Gleadow RM, Zacarias AM, Cuambe CE, Miller RE, Cavagnaro TR (2012). Variations in the chemical composition of cassava (Manihot esculenta Crantz) leaves and roots as affected by genotypic and environmental variation. Journal of Agricultural and Food Chemistry 60(19):4946-4956.

Cardoso IM, Kuyper TW (2006). Mycorrhizas and tropical soil fertility. Agriculture, Ecosystems and Environment 116(1-2):72-84.

Carrenho R, Trufem SFB, Bononi VLR, Silva ES (2007). The effect of different soil properties on arbuscular mycorrhizal colonization of peanuts, sorghum and maize. Acta Botanica Brasilica21(3):723-730.

Carretero CL, Cantos M, Garcia JL, Azcon R, Troncoso A (2009). Growth response of micropropagated cassava clones as affected by Glomus intraradices colonization. Journal of Plant Nutrition 32(2):261-273.

Ceballos I, Ruiz M, Fernandez C, Pena R, Rodriguez A, Sanders IR (2013). The in vitro mass-produced model mycorrhizal fungus, Rhizophagus irregularis, significantly increases yields of the globally important food security crop cassava. PLoSOne 8(8):70633.

Cordones MN, Alemán F, Martínez V, Rubio F (2014). $\mathrm{K}^{+}$uptake in plant roots. The systems involved their regulation and parallels in other organisms. Journal of Plant Physiology 171(9):688-695.

Dickson S (2004). The Arum-Paris continuum of mycorrhizal symbioses. New Phytologyst 163(1):187-200.
Dickson S, Smith FA, Smith SE (2007). Structural differences in arbuscular mycorrhizal symbioses: more than 100 years after Gallaud, where next? Mycorrhiza 17(5):375-393.

Duran C (2014). Relationship between rainfall distribution and physical geography elements within Mersin province, turkey. Procedia-Social and Behavioral Sciences 120:740-748.

Edison S, Anantharaman M, Srinivas T (2006). Status of cassava in India, an overall view. Technical Bulletin 46, Published by the Director, Central Tuber Crops Research Institute, Thiruvananthapuram, Kerala, India

Figueiredo PG, Moraes-Dallaqua MA, Bicudo SJ, Tanamati FY, Aguiar EB (2015). Development of tuberous cassava roots under different tillage systems: descriptive anatomy. Plant Production Science 18(3):241-245.

Garcia K, Zimmermann SD (2014). The role of mycorrhizal associations in plant potassium nutrition. Frontiers in Plant Science 5:3-37.

Hammer y, Harper DA T, Ryan PD (2001). Paleontological statistics software: package for education and data analysis. Palaeontologia Electronica 4.

Herren HR, Bennett FD (1984). Biological control of cassava pests. In: Advancing agricultural production in Africa. Proceedings, CAB's Scientific Conference, edited by D.L. Hawksworth, pp 12-18.

Howeler RH (2002). Cassava mineral nutrition and fertilization. In Hillocks RJ, Thresh MJ and Bellotti AC.(eds) Cassava biology, production and utilization. CABI publishing $\mathrm{CAB}$ International, Wallingford, Oxon, UK.

Howler R, Lutaladio N, Thomas G (2013). Save and grow: Cassava - A guide to sustainable production intensification. Food and Agriculture Organization of the United States of America, Rome.

IMD (2013). Temperature of Salem District. Regional Meterological Centre, Chennai, India.

Jackson ML (1971). Soil Chemical Analysis. Prentice Hall, New Delhi, India.

Karthigairaj M, Kalaiarasu S (2015). Biodiversity of AM fungi in the cassava grown soils of semiarid tropics of Tamilnadu. Asian Journal of Science and Technology 6:1815-1818.

Khade SW, Rodrigues BF (2009). Arbuscular mycorrhizal fungi associated with varieties of Carica papaya $\mathrm{L}$. in tropical agro-based ecosystem of Goa, India. Tropical and Subtropical Agroecosystem 10(3):369-381.

Khan MA, Gemenet DC, Villordon A (2016). Root system architecture and abiotic stress tolerance: current knowledge in root and tuber crops. Frontiers in Plant Science 7:1584.

Knapp DG, Pintye A, Kovacs GM (2012). The dark side is not fastidious dark septate endophytic fungi of native and invasive plants of semiarid sandyareas. PLoSOne 7(2):e32570.

Koske RE, Gemma JN (1989). A modified procedure for staining roots to detect VA mycorrhizas. Mycological Research 92(4):486-488.

Lebot V, Champagne A, Malapa R, Shirley D (2009).NIR determination of major constituents in tropical root and tuber crop flours. Journal of Agricultural and Food Chemistry 57(22):10539-10547.

Legris P, Meher-Homji VM (1984). The Eastern Ghats: phytogeographic aspects. International Journal of Life-Sciences Scientific Research 4:115136.

Lendenmann M, Thonar C, Barnard R, Salmon Y, Werner R, ... Jansa J (2011). Symbiont identity matters: carbon and phosphorus fluxes 
166

between Medicago truncatula and different arbuscular mycorrhizal fungi. Mycorrhiza 21(8):689-702.

Lindsay WL, Norvell WA (1978). Development of a DTPA soil test for Zn, $\mathrm{Fe}, \mathrm{Mn}$, and Cd. Soil Science Society of America Journal 42(3):421-428.

Liu C, Ravnskov S, Liu F, Rubæk GH, Andersen MN (2018). Arbuscular mycorrhizal fungi alleviate abiotic stresses in potato plants caused by low phosphorus and deficit irrigation/partial rootzone drying. The Journal of Agricultural Science 156(1):46-58.

Liu W, Zhang Y, JiangS, Deng Y, Christie P, Murray PJ, ... ZhangJ (2016). Arbuscular mycorrhizal fungi in soil and roots respond differently to phosphorus inputs in an intensively managed calcareous agricultural soil. Scientific Report 6:24902.

MaZ, BielenbergDG, Brown KM,LynchJP(2001). Regulation of root hair density by phosphorus availability in Arabidopsis thatiana. Plant Cell Environment 24(4):459-467.

Magurran AE (2004). Measuring biological diversity. Oxford: Blackwell Science. United Kingdom. USA.

Maherali H (2014). There an association between root architecture and mycorrhizal growth response. New Phytologist 204(1):192-200.

Mandyam K, Jumpponen A (2005). Abundance and possible functions of the root-colonising dark septate endophytic fungi. Studies in Mycology 53:173-190

Mandyam K, Loughin T, Jumpponen A (2010). Isolation and morphological and metabolic characterization of common endophytes in annually burned tall grass prairie. Mycologia 102(4):813-821.

Marschner H, Dell B (1994). Nutrient uptake in mycorrhizal symbiosis. Plant and Soil 159(1):89-102.

Mathimaran N, Ruh R, Jama B, Verchot L, Frossard E, Jansa J (2007). Impact of agricultural management on arbuscular mycorrhizal fungal communities in Kenya ferrasol. Agriculture, Ecosystems andEnvironment 119(1-2):22-23.

McGonigle TP, Miller MH, Evans DG, Fairchild GL, Swan JA (1990). A new method which gives an objective measure of colonization of roots by vesicular-arbuscular mycorrhizal fungi. New Phytologist 115(3):495501.

Medina RD, Faloci MM, Gonzalez AM, Mroginski LA (2007).In vitro cultured primary roots derived from stem segments of cassava (Manihot esculenta Crantz) can behave like storage organs. Annals of Botany 99(3):409-423.

Muthukumar T, Tamilselvi V (2010). Occurrence and morphology of endorhizal fungi in crop species. Tropical andSubtropical Agroecosystems 12(3):593-604.

Muthukumar T, Udaiyan K (2000). Arbuscular mycorrhizas of plants growing in the Western Ghats region, Southern India. Mycorrhiza 9(6):297-313.

Newsham KK (2011). A meta-analysis of plant responses to dark septate root endophytes. New Phytologist 190(3):783-793.

Roldan ME, Arredondo JT, Huber-Sannwald E, Chapa-Vargas L, Portugal VO (2008). Grazing effects on fungal root symbionts and carbon and nitrogen storage in a short grass steppe in Central Mexico. Journal of AridEnvironment 72(4):546-556.

Okon IE, Solomon MG, Osonubi O (2010). The effects of arbuscular mycorrhizal fungal inoculation and mulch of contrasting chemical composition on the yield of cassava under humid tropical conditions.
The Scientific WorldJournal 10:505-511.

Ouimet R, Camire C, Furlan V (1996). Effect of soil K, Ca and Mg saturation and endomycorrhization on growth and nutrient uptake of sugar maple seedlings. Plant and Soil 179(2):207-216.

Oyetunji OJ, Osonubi O (2007). Assessment of influence of alley cropping system and arbuscular mycorrhizal (AM) fungi on cassava productivity in derived savanna zone of Nigeria. World Journal of Agricultural Science 3(4):489-495.

Peterson RL, Wagg C, Pautler M(2008). Associations between micro fungal endophytes and roots: do structural features indicate function? Botany $86(5): 445-456$

Postma JW M, Olsson PA, Grerup UF (2007). Root colonization by arbuscular mycorrhizal, fine endophytic and dark septate fungi across a $\mathrm{pH}$ gradient in acid beech forests. Soil Biology and Biochemistry 39(2):400-408

Reininger V, Grunig CR, Sieber TN (2012). Host species and strain combination determine growth reduction of spruce and birch seedlings colonized by root-associated dark septate endophytes. Environmental Microbiology 14(4):1064-1076.

Rogers D, Appan C (1973). Manihot, Manihotoides, Euphorbiaceae. Flora Neotropica Hafner Press, New York.

Schüßler A, Schwarzott D, Walker C (2001). A new fungal phylum, the Glomeromycota: phylogeny and evolution. Mycological Research 105(12):1413-1421.

Schüßler A, Walker C (2010). The Glomeromycota. A species list with new families and new genera: Published in December 2010 in libraries at The Royal Botanic Garden Edinburgh, The Royal Botanic Garden Kew, Botanische Staatssammlung Munich, and Oregon State University.

Smith FA, Smith SE (2011). What is the significance of the arbuscular mycorrhizal colonization of many economically important crop plants. Plant and Soil 348(1-2):63-79.

Smith SE, Read DJ (2008). Mycorrhizal Symbiosis.3rd edition. Academic Press.London.

Sreenivas T, Anantharaman M (2005). Cassava marketing systems in India. Tech Bull Series 43:1-162.

Straker CJ, Hilditch AJ, Rey ME C (2010). Arbuscular mycorrhizal fungi associated with cassava (Manihot esculenta Crantz) in South Africa. South African Journal of Botany 76(1):102-111.

Subramanian KS, Selvan TA (2001). Geology of Tamilnadu and Pondicherry. Geological Society of India, Bangalore.

Tchabi A, Hountondji FCC, Ogunsola B, Lawouin L, Coyne D, Wiemken A, Oehl F (2016). The influence of arbuscular mycorrhizal fungi inoculation on micro-propagated hybrid Yam (Dioscorea spp.) growth and root knot nematode (Meloidogyne sp.) suppression. IJCMAS 5:267-281.

Villordon AQ, Ginzberg I, Firon N (2014). Root architecture and root and tuber crop productivity. Trends in Plant Science 19(7):419-425.

Voko RR, Nandjui J, Seryjm D, Fotso B, AmoJA, Kouadi MSA, ... Zeze A (2013). Abundance and diversity of arbuscular mycorrhizal fungal (AMF) communities associated with cassava (Manihot esculenta Crantz) rhizosphere in Abengourou. East Coted Ivoire 5(11):360-370.

Willis AB, Rodrigues F, Harris PJC (2013). The ecology of arbuscular mycorrhizal fungi. Critical Reviews in Plant Sciences 32(1):1-20. 
Table S1. Details of cassava varieties used in the present study

Annexes

\begin{tabular}{|c|c|c|c|}
\hline Cassava variety & Starch content (\%) & Yield ( $\mathrm{t} / \mathrm{ha}$ ) & Crop duration (months) \\
\hline $\mathrm{CO}$ (T.P) 4 & 40 & 42 & 10 \\
\hline $\mathrm{CO} 1$ & 32 & $22.90-36.50$ & $10-11$ \\
\hline $\mathrm{CO}-3$ & 30 & $32-35 \mathrm{t} / \mathrm{ha}$ & $71 / 2-8$ \\
\hline $\mathrm{H}-165$ & $23-25$ & $33-38$ & $8-9$ \\
\hline $\mathrm{H} 226$ & $27-29$ & $30-35$ & 10 \\
\hline Kerala rose & $23-25$ & $13-15$ & $81 / 2$ \\
\hline Mulluvadi - 1 & 35 & 34.5 & 9 \\
\hline Rasi - 20 & 28 & $16-17$ & $91 / 2$ \\
\hline Sree Athulya & 30 & 38 & 10 \\
\hline Sree Rekha & $28-30$ & 48.0 & $8-10$ \\
\hline Sri Jaya & $24-29$ & $26-30$ & 6 \\
\hline Sri Vijaya & $27-30$ & $25-28$ & 6 \\
\hline Yethapur - 1 & $25-27$ & 50 & $91 / 2$ \\
\hline
\end{tabular}

Table S2. Root characteristics of different varieties of cassava

\begin{tabular}{|c|c|c|c|c|}
\hline \multirow{2}{*}{ Variety name } & \multicolumn{4}{|c|}{ "Root characteristics } \\
\hline & $\mathrm{RD}(\mu \mathrm{m})$ & RHN (per cm) & $\operatorname{RHL}(\mu \mathrm{m})$ & RHW $(\mu \mathrm{m})$ \\
\hline Yethapur-1 & $991.03 \pm 62.45 \mathrm{e}$ & $138.67 \pm 61.37 \mathrm{bcd}$ & $77.33 \pm 14.55 \mathrm{bcd}$ & $14.67 \pm 2.98^{\mathrm{bc}}$ \\
\hline Mulluvadi-1 & $1070.25 \pm 71.99 \mathrm{de}$ & $100.67 \pm 40.27 \mathrm{~d}-\mathrm{g}$ & $66.67 \pm 16.86 \mathrm{~cd}$ & $14.67 \pm 4.29^{\mathrm{bc}}$ \\
\hline $\mathrm{CO}(\mathrm{T} . \mathrm{P}) 4$ & $532.79 \pm 79.24 \mathrm{~h}$ & $40.67 \pm 19.33 \mathrm{~g}$ & $73.33 \pm 25.51 \mathrm{~cd}$ & $14.00 \pm 3.65 b c$ \\
\hline $\mathrm{CO} 1$ & $768.90 \pm 33.73 \mathrm{fg}$ & $162.67 \pm 56.21 \mathrm{abc}$ & $93.33 \pm 14.75 \mathrm{abc}$ & $16.00 \pm 4.25 b c$ \\
\hline Sri Vijaya & $615.12 \pm 62.65 \mathrm{~h}$ & $200.67 \pm 70.19 a$ & $113.33 \pm 20.08 \mathrm{a}$ & $14.67 \pm 4.29 b c$ \\
\hline $\mathrm{Co}-3$ & $1025.20 \pm 44.62 \mathrm{e}$ & $86.67 \pm 39.32 \mathrm{~d}-\mathrm{g}$ & $76.67 \pm 31.14 \mathrm{bcd}$ & $12.00 \pm 2.39 \mathrm{c}$ \\
\hline Kerala rose & $841.91 \pm 93.18 \mathrm{f}$ & $108.00 \pm 35.94 c-f$ & $76.00 \pm 20.56 \mathrm{bcd}$ & $14.67 \pm 2.98 b c$ \\
\hline Sree Athulya & $1439.94 \pm 67.11 \mathrm{~b}$ & $137.33 \pm 46.62 \mathrm{~b}-\mathrm{e}$ & $92.00 \pm 19.79 \mathrm{abc}$ & $19.33 \pm 4.61 \mathrm{ab}$ \\
\hline Rasi-20 & $723.85 \pm 99.70 \mathrm{~g}$ & $42.00 \pm 10.74 \mathrm{~g}$ & $53.33 \pm 16.13 \mathrm{~d}$ & $22.67 \pm 8.58 \mathrm{a}$ \\
\hline $\mathrm{H}-165$ & $1135.49 \pm 64.01 \mathrm{~d}$ & $78.00 \pm 37.11 \mathrm{efg}$ & $66.67 \pm 18.34 \mathrm{~cd}$ & $14.00 \pm 2.93 b c$ \\
\hline Sri Jaya & $1533.14 \pm 73.01 \mathrm{a}$ & $178.67 \pm 43.53 \mathrm{ab}$ & $104.67 \pm 21.48 \mathrm{ad}$ & $18.00 \pm 4.98 \mathrm{abc}$ \\
\hline $\mathrm{H} 226$ & $1343.63 \pm 56.31 \mathrm{c}$ & $59.33 \pm 18.19 \mathrm{fg}$ & $63.33 \pm 13.39 \mathrm{~cd}$ & $18.67 \pm 5.72 \mathrm{abc}$ \\
\hline Sree Rekha & $994.13 \pm 84.42 \mathrm{e}$ & $83.33 \pm 20.66 \mathrm{~d}-\mathrm{g}$ & $82.67 \pm 32.18 \mathrm{bcd}$ & $14.67 \pm 3.69 \mathrm{bc}$ \\
\hline$F_{(12,194)}$ & $94.696^{* * *}$ & $7.449^{* * *}$ & $3.228^{* * *}$ & $2.025^{* *}$ \\
\hline
\end{tabular}

Mean \pm SE followed by same letter $(s)$ are not significantly $(\mathrm{p}>0.05)$ different according to DMRT.

${ }_{* * *}$ Significant at $0.1 \%$ level

Table S3. The extent of arbuscular mycorrhizal (AM) fungal colonization in different varieties of cassava

\begin{tabular}{|c|c|c|c|c|c|c|}
\hline \multirow{2}{*}{$\begin{array}{l}\text { Tapioca } \\
\text { Variety }\end{array}$} & \multicolumn{6}{|c|}{ AM colonization (\%) } \\
\hline & RHL & RLHC & RLA & RLAC & RLV & RLTC \\
\hline $\mathrm{CO}$ (Т.P) 4 & $23.80 \pm 1.75 \mathrm{abc}$ & $25.99 \pm 0.41 \mathrm{abc}$ & $17.48 \pm 0.42 \mathrm{abc}$ & $12.94 \pm 0.60 \mathrm{~cd}$ & - & $80.22 \pm 2.22 \mathrm{abc}$ \\
\hline $\mathrm{COl}$ & $27.36 \pm 0.98 \mathrm{ab}$ & $18.49 \pm 4.30 \mathrm{bc}$ & $13.88 \pm 3.32 \mathrm{bc}$ & $17.24 \pm 4.66 \mathrm{abc}$ & - & $76.97 \pm 3.56 \mathrm{abc}$ \\
\hline $\mathrm{CO}-3$ & $23.77 \pm 5.28 \mathrm{abc}$ & $15.87 \pm 4.01 \mathrm{c}$ & $17.81 \pm 1.76 \mathrm{abc}$ & $13.45 \pm 2.55 \mathrm{bcd}$ & $3.32 \pm 1.91 \mathrm{~cd}$ & $74.22 \pm 0.98 \mathrm{c}$ \\
\hline H-165 & $9.91 \pm 1.93 \mathrm{~d}$ & $25.73 \pm 2.85 \mathrm{abc}$ & $14.75 \pm 1.62 \mathrm{abc}$ & $20.68 \pm 3.22 \mathrm{ab}$ & $2.12 \pm 2.12 \mathrm{~cd}$ & $73.19 \pm 7.31 \mathrm{c}$ \\
\hline $\mathrm{H} 226$ & $32.02 \pm 1.33 \mathrm{a}$ & $16.69 \pm 3.35 \mathrm{c}$ & $6.09 \pm 2.68 \mathrm{~d}$ & $20.86 \pm 1.19 a$ & - & $75.66 \pm 1.98 \mathrm{bc}$ \\
\hline Kerala rose & $22.43 \pm 3.39 \mathrm{abc}$ & $22.69 \pm 6.11 b c$ & $21.50 \pm 3.82 \mathrm{a}$ & $18.36 \pm 1.43 \mathrm{abc}$ & - & $84.98 \pm 4.01 \mathrm{abc}$ \\
\hline Mulluvadi - 1 & $28.87 \pm 3.62 \mathrm{ab}$ & $16.76 \pm 2.22 \mathrm{c}$ & $14.68 \pm 2.68 \mathrm{abc}$ & $16.10 \pm 1.40 \mathrm{abc}$ & $4.97 \pm 4.21 \mathrm{bcd}$ & $81.38 \pm 4.36 \mathrm{abc}$ \\
\hline Rasi - 20 & $20.85 \pm 5.87 b c$ & $22.57 \pm 4.76 \mathrm{bc}$ & $18.89 \pm 2.67 \mathrm{ab}$ & $15.35 \pm 1.86 \mathrm{abc}$ & $1.56 \pm 0.84 \mathrm{~d}$ & $79.22 \pm 1.80 \mathrm{abc}$ \\
\hline Sree Athulya & $15.98 \pm 3.28 \mathrm{~cd}$ & $37.32 \pm 6.72 \mathrm{a}$ & $10.37 \pm 0.22 \mathrm{~cd}$ & $8.15 \pm 0.68 \mathrm{~d}$ & $1.66 \pm 1.00 \mathrm{~cd}$ & $73.48 \pm 4.23 \mathrm{c}$ \\
\hline Sree Rekha & $21.13 \pm 1.67 \mathrm{abc}$ & $22.73 \pm 1.54 \mathrm{bc}$ & $10.59 \pm 2.44 \mathrm{~cd}$ & $19.38 \pm 1.03 \mathrm{abc}$ & $2.24 \pm 1.14 \mathrm{~cd}$ & $76.08 \pm 4.22 \mathrm{bc}$ \\
\hline Sri Jaya & $16.08 \pm 4.65 \mathrm{~cd}$ & $21.92 \pm 4.04 b c$ & $5.24 \pm 1.55 \mathrm{~d}$ & $14.59 \pm 3.17 \mathrm{a}-\mathrm{d}$ & $26.01 \pm 2.54 \mathrm{a}$ & $83.84 \pm 3.50 \mathrm{abc}$ \\
\hline Sri Vijaya & $23.58 \pm 2.54 \mathrm{abc}$ & $30.60 \pm 2.29 \mathrm{ab}$ & $14.50 \pm 1.86 \mathrm{abc}$ & $12.51 \pm 1.50 \mathrm{~cd}$ & $7.56 \pm 1.32 \mathrm{bc}$ & $88.74 \pm 1.96 \mathrm{a}$ \\
\hline Yethapur - 1 & $29.42 \pm 0.24 \mathrm{ab}$ & $20.72 \pm 2.35 b c$ & $5.45 \pm 0.87 \mathrm{~d}$ & $21.22 \pm 1.24 \mathrm{a}$ & $10.37 \pm 2.33 b$ & $87.19 \pm 3.56 \mathrm{ab}$ \\
\hline $\mathrm{F}_{(12,38)}$ & $3.558^{* *}$ & $2.438^{*}$ & $5.551^{* * *}$ & $3.139^{*}$ & $15.712^{* * *}$ & $2.027^{*}$ \\
\hline
\end{tabular}

Mean \pm SE followed by same letter (s) are not significantly $(\mathrm{p}>0.05)$ different according to DMRT.

${ }^{* * *}$ Significant at $0.1 \%$ level, ${ }^{*}$ Significant at $5 \%$ level 
Table S4. Extent of dark septate endophytic (DSE) fungal colonization in different varieties of cassava

\begin{tabular}{|c|c|c|c|c|}
\hline \multirow{2}{*}{ Cassava variety } & \multicolumn{4}{|c|}{ DSE colonization (\%) } \\
\hline & RLDH & RLMO & RLMI & RLDTC \\
\hline $\mathrm{CO}$ (T.P) 4 & $22.30 \pm 4.60 \mathrm{cde}$ & $3.81 \pm 1.98 \mathrm{a}$ & - & $23.89 \pm 5.80 \mathrm{c}$ \\
\hline $\mathrm{CO} 1$ & $28.71 \pm 5.07 \mathrm{a}-\mathrm{d}$ & $3.72 \pm 2.11 \mathrm{a}$ & $28.63 \pm 1.54 c$ & $59.78 \pm 8.57 \mathrm{ab}$ \\
\hline $\mathrm{CO}-3$ & $2.75 \pm 1.60 \mathrm{f}$ & - & $44.89 \pm 3.30 \mathrm{a}$ & $46.74 \pm 4.88 \mathrm{~b}$ \\
\hline H-165 & $39.15 \pm 1.95 \mathrm{abc}$ & - & $28.48 \pm 4.99 c$ & $67.63 \pm 6.65 \mathrm{a}$ \\
\hline H226 & - & - & $39.92 \pm 3.33 \mathrm{ab}$ & $39.92 \pm 3.33 \mathrm{bc}$ \\
\hline Kerala rose & $5.00 \pm 8.33 \mathrm{ef}$ & - & - & $13.33 \pm 2.55 \mathrm{de}$ \\
\hline Mulluvadi - 1 & $44.87 \pm 1.59 \mathrm{a}$ & $3.71 \pm 2.07 \mathrm{a}$ & - & $48.58 \pm 2.48 \mathrm{ab}$ \\
\hline Rasi - 20 & $24.29 \pm 3.10 \mathrm{bcd}$ & - & $33.40 \pm 3.90 \mathrm{bc}$ & $57.70 \pm 4.85 \mathrm{ab}$ \\
\hline Sree Athulya & $15.89 \pm 10.09 \mathrm{def}$ & - & $6.21 \pm 4.23 \mathrm{~d}$ & $22.10 \pm 6.32 \mathrm{~cd}$ \\
\hline Sree Rekha & $12.48 \pm 7.89 \mathrm{def}$ & - & $39.73 \pm 5.49 \mathrm{ab}$ & $52.20 \pm 3.11 \mathrm{ab}$ \\
\hline SriJaya & - & - & - & - \\
\hline Sri Vijaya & $36.75 \pm 6.88 \mathrm{abc}$ & - & $30.56 \pm 1.10 \mathrm{c}$ & $67.32 \pm 7.62 \mathrm{a}$ \\
\hline Yethapur - 1 & $41.72 \pm 9.79 \mathrm{ab}$ & $2.38 \pm 2.38 \mathrm{a}$ & - & $44.10 \pm 11.01 \mathrm{~b}$ \\
\hline $\mathrm{F}_{(12,38)}$ & $8.839^{* * *}$ & $1.180^{*}$ & $38.378^{* * *}$ & $13.574^{* * *}$ \\
\hline
\end{tabular}

${ }^{*}$ RLDH, RLMO, RLMI, RLDTC - root length with dark septate endophytic fungal hyphae, moniliform hyphae, microsclerotia and total colonization respectively.Mean \pm SE followed by same superscript $(s)$ are not significantly $(p>0.05)$ different according to DMRT.

${ }^{* * *}$ Significant at $0.1 \%$ level, ${ }^{* *}$ Significant at $1 \%$ level, ${ }^{*}$ Significant at $5 \%$ level

Table S5. Average values of edaphic factors in relationship with 13 varieties of cassava

\begin{tabular}{|c|c|c|c|c|c|c|c|c|c|}
\hline \multirow{2}{*}{ Variety } & \multicolumn{5}{|c|}{${ }^{*}$ Macronutrients $(\mathrm{Kg} / \mathrm{Ha})$} & \multicolumn{4}{|c|}{${ }^{* \theta}$ Micronutrients $\left(\mu \mathrm{g} \mathrm{g}^{-1}\right)$} \\
\hline & $\mathrm{EC}\left(\mathrm{d} S \mathrm{~m}^{-1}\right)$ & $\mathrm{pH}$ & $\mathrm{N}$ & $\mathrm{P}$ & $\mathrm{K}$ & $\mathrm{Fe}$ & $\mathrm{Mg}$ & $\mathrm{Zn}$ & $\mathrm{Cu}$ \\
\hline \multirow{2}{*}{$\mathrm{CO}(\mathrm{T} . \mathrm{P}) 4$} & $0.147 \pm 0.003$ & $6.233 \pm 0.067 \mathrm{~b}-$ & $66.33 \pm 0.67$ & $5.07 \pm 0.07$ & $240.67 \pm 0.33$ & $5.57 \pm 0.13$ & $2.63 \pm 0.07$ & $1.02 \pm 0.04$ & $1.51 \pm 0.02$ \\
\hline & gh & e & de & d & b & a & d & bc & $\mathrm{ab}$ \\
\hline \multirow{2}{*}{$\mathrm{CO}-1$} & $0.137 \pm 0.003$ & $6.167 \pm 0.067$ & $54.33 \pm 0.88$ & $4.50 \pm 0.06$ & $179.33 \pm 0.33$ & $5.47 \pm 0.03$ & $2.79 \pm 0.01$ & $0.77 \pm 0.07$ & $1.37 \pm 0.02$ \\
\hline & gh & $a-d$ & i & $\mathrm{e}$ & e & a & c & d & cde \\
\hline \multirow{2}{*}{$\mathrm{CO}-3$} & $0.187 \pm 0.007$ & $6.127 \pm 0.058$ & $64.53 \pm 0.29$ & $6.07 \pm 0.03$ & $154.33 \pm 0.33$ & $4.77 \pm 0.03$ & $2.33 \pm 0.04$ & $1.26 \pm 0.07$ & $1.26 \pm 0.03$ \\
\hline & cd & cde & $\mathrm{f}$ & $\mathrm{a}$ & $\mathrm{g}$ & c & $\mathrm{e}$ & a & $\mathrm{e}$ \\
\hline \multirow{2}{*}{ H-165 } & $0.167 \pm 0.003$ & $6.357 \pm 0.062$ & $66.67 \pm 0.33$ & $5.63 \pm 0.03$ & $145.33 \pm 0.33$ & $5.17 \pm 0.12$ & $2.83 \pm 0.03$ & $1.07 \pm 0.04$ & $1.35 \pm 0.02$ \\
\hline & ef & $\mathrm{ab}$ & d & $\mathrm{b}$ & $\mathrm{h}$ & $\mathrm{b}$ & c & $\mathrm{b}$ & cde \\
\hline \multirow{2}{*}{$\mathrm{H} 226$} & $0.137 \pm 0.003$ & $6.237 \pm 0.091$ & $87.05 \pm 0.05$ & $5.57 \pm 0.03$ & $224.67 \pm 0.33$ & $5.10 \pm 0.06$ & $2.36 \pm 0.05$ & $1.08 \pm 0.01$ & $1.53 \pm 0.03$ \\
\hline & gh & b-e & a & $\mathrm{bc}$ & c & b & $\mathrm{e}$ & b & a \\
\hline \multirow{2}{*}{ Kerala rose } & $0.133 \pm 0.003$ & $6.423 \pm 0.009$ & $56.33 \pm 0.33$ & $5.07 \pm 0.07$ & $145.33 \pm 0.33$ & $5.20 \pm 0.06$ & $2.58 \pm 0.01$ & $0.86 \pm 0.03$ & $1.62 \pm 0.05$ \\
\hline & h & a & $\mathrm{h}$ & $\mathrm{d}$ & $\mathrm{h}$ & $\mathrm{b}$ & $\mathrm{d}$ & $\mathrm{cd}$ & $\mathrm{a}$ \\
\hline \multirow{2}{*}{ Mulluvadi - 1} & $0.210 \pm 0.012$ & $6.267 \pm 0.033 \mathrm{a}-$ & $62.33 \pm 0.33$ & $5.13 \pm 0.09$ & $245.33 \pm 0.33$ & $4.10 \pm 0.06$ & $2.78 \pm 0.01$ & $0.93 \pm 0.09$ & $1.40 \pm 0.01$ \\
\hline & b & d & g & d & a & e & c & bcd & $\mathrm{cd}$ \\
\hline \multirow{2}{*}{ Rasi - 20} & $0.190 \pm 0.006$ & $6.233 \pm 0.033 b-$ & $86.67 \pm 0.33$ & $5.43 \pm 0.03$ & $223.33 \pm 1.76$ & $5.63 \pm 0.09$ & $2.55 \pm 0.08$ & $0.91 \pm 0.03$ & $1.59 \pm 0.04$ \\
\hline & $\mathrm{c}$ & e & a & $\mathrm{c}$ & c & a & d & bcd & a \\
\hline \multirow{2}{*}{ Sree Athulya } & $0.157 \pm 0.003$ & $6.497 \pm 0.007$ & $65.00 \pm 1.00$ & $5.50 \pm 0.06$ & $161.33 \pm 0.67$ & $5.47 \pm 0.07$ & $3.20 \pm 0.05$ & $0.92 \pm 0.03$ & $1.42 \pm 0.01$ \\
\hline & $\mathrm{fg}$ & $\mathrm{a}$ & ef & bc & $\mathrm{f}$ & $\mathrm{a}$ & $\mathrm{b}$ & $\mathrm{bcd}$ & $\mathrm{bc}$ \\
\hline \multirow{2}{*}{ Sree Rekha } & $0.600 \pm 0.010$ & $6.307 \pm 0.009$ & $67.33 \pm 0.33$ & $5.17 \pm 0.07$ & $192.00 \pm 1.53$ & $4.40 \pm 0.10$ & $3.47 \pm 0.07$ & $1.07 \pm 0.10$ & $1.30 \pm 0.02$ \\
\hline & a & $a b c$ & d & d & d & d & a & b & de \\
\hline \multirow{2}{*}{ Sri Jaya } & $0.177 \pm 0.003$ & $6.067 \pm 0.088$ & $87.33 \pm 0.33$ & $5.60 \pm 0.06$ & $180.67 \pm 0.67$ & $4.43 \pm 0.15$ & $2.92 \pm 0.08$ & $1.02 \pm 0.04$ & $1.33 \pm 0.09$ \\
\hline & def & $\mathrm{e}$ & $\mathrm{a}$ & $\mathrm{bc}$ & e & d & c & bc & cde \\
\hline \multirow{2}{*}{ Sri Vijaya } & $0.147 \pm 0.003$ & $6.433 \pm 0.039$ & $70.86 \pm 0.46$ & $5.10 \pm 0.06$ & $241.33 \pm 0.67$ & $4.80 \pm 0.06$ & $2.39 \pm 0.01$ & $0.85 \pm 0.03$ & $1.62 \pm 0.02$ \\
\hline & gh & $\mathrm{ab}$ & c & d & b & c & e & $\mathrm{cd}$ & $\mathrm{a}$ \\
\hline \multirow{2}{*}{ Yethapur - 1} & $0.177 \pm 0.003$ & $6.133 \pm 0.033$ & $84.33 \pm 0.33$ & $5.13 \pm 0.03$ & $239.33 \pm 0.67$ & $4.47 \pm 0.09$ & $3.19 \pm 0.02$ & $1.02 \pm 0.04$ & $1.27 \pm 0.03$ \\
\hline & cde & de & b & d & b & d & b & bc & $\mathrm{e}$ \\
\hline $\mathrm{F}_{(12,38)}$ & $425.05^{* * *}$ & $4.47^{* * *}$ & $540.12^{* * *}$ & $48.2^{* * *}$ & $250.3^{* * *}$ & $33.86^{* * *}$ & $56.7^{* * *}$ & $5.69^{* * *}$ & $14.21^{* * *}$ \\
\hline
\end{tabular}

*** Significant at $0.1 \%$ level.

Mean \pm SE followed by same letter $(s)$ are not significantly $(\mathrm{p}>0.05)$ different according to DMRT.

$\mathrm{EC}$,electrical conductivity; $\mathrm{pH}$, power of hydrogen

${ }^{\#} \mathrm{~N}$, nitrogen; P, phosphorus; K, potassium

${ }^{\# *} \mathrm{Fe}$, iron; $\mathrm{Mn}$, manganese; $\mathrm{Zn}$, zinc; $\mathrm{Cu}$, copper. 
III

Table S6. Arbuscular mycorrhizal fungal species richness, spore abundance and diversity indices for cassava varieties.

\begin{tabular}{|c|c|c|c|c|c|}
\hline Variety & Species richness & Spore abundance & Simpson_1-D & Shannon_H & Evenness_$\_{ }^{\wedge} \mathrm{H} / \mathrm{S}$ \\
\hline $\mathrm{CO}(\mathrm{T} . \mathrm{P}) 4$ & $4.67 \pm 0.33$ & $22.67 \pm 0.88$ & $0.76 \pm 0.02$ & $1.48 \pm 0.08$ & $0.95 \pm 0.01$ \\
\hline $\mathrm{CO} 1$ & $4.00 \pm 0.00$ & $19.67 \pm 1.20$ & $0.72 \pm 0.02$ & $1.30 \pm 0.04$ & $0.92 \pm 0.04$ \\
\hline $\mathrm{CO}-3$ & $8.00 \pm 0.00$ & $36.33 \pm 2.19$ & $0.85 \pm 0.01$ & $1.98 \pm 0.03$ & $0.91 \pm 0.03$ \\
\hline $\mathrm{H}-165$ & $8.67 \pm 0.33$ & $48.67 \pm 6.12$ & $0.86 \pm 0.01$ & $2.05 \pm 0.06$ & $0.90 \pm 0.02$ \\
\hline H226 & $10.00 \pm 0.00$ & $76.33 \pm 4.70$ & $0.88 \pm 0.01$ & $2.20 \pm 0.03$ & $0.91 \pm 0.03$ \\
\hline Kerala rose & $5.00 \pm 0.00$ & $21.33 \pm 4.26$ & $0.73 \pm 0.05$ & $1.47 \pm 0.10$ & $0.88 \pm 0.08$ \\
\hline Mulluvadi & $9.00 \pm 0.00$ & $40.67 \pm 3.18$ & $0.85 \pm 0.00$ & $2.01 \pm 0.02$ & $0.83 \pm 0.01$ \\
\hline Rasi - 20 & $4.00 \pm 0.00$ & $22.00 \pm 1.53$ & $0.71 \pm 0.02$ & $1.30 \pm 0.06$ & $0.92 \pm 0.05$ \\
\hline Sree Athulya & $4.00 \pm 0.00$ & $20.33 \pm 2.85$ & $0.69 \pm 0.02$ & $1.26 \pm 0.05$ & $0.88 \pm 0.04$ \\
\hline Sree Rekha & $7.00 \pm 0.00$ & $42.67 \pm 4.81$ & $0.85 \pm 0.00$ & $1.91 \pm 0.01$ & $0.96 \pm 0.01$ \\
\hline Sri Jaya & $4.67 \pm 0.33$ & $26.33 \pm 1.76$ & $0.73 \pm 0.02$ & $1.39 \pm 0.08$ & $0.87 \pm 0.07$ \\
\hline Sri Vijaya & $6.67 \pm 0.33$ & $34.33 \pm 3.84$ & $0.82 \pm 0.01$ & $1.81 \pm 0.06$ & $0.92 \pm 0.02$ \\
\hline Yethapur & $9.67 \pm 0.33$ & $39.67 \pm 6.36$ & $0.86 \pm 0.02$ & $2.09 \pm 0.10$ & $0.84 \pm 0.05$ \\
\hline$F_{(12,38)}$ & 123.67 & 17.66 & $12.02 \ldots$ & $32.94 \cdots$ & $0.81^{\text {ns }}$ \\
\hline
\end{tabular}
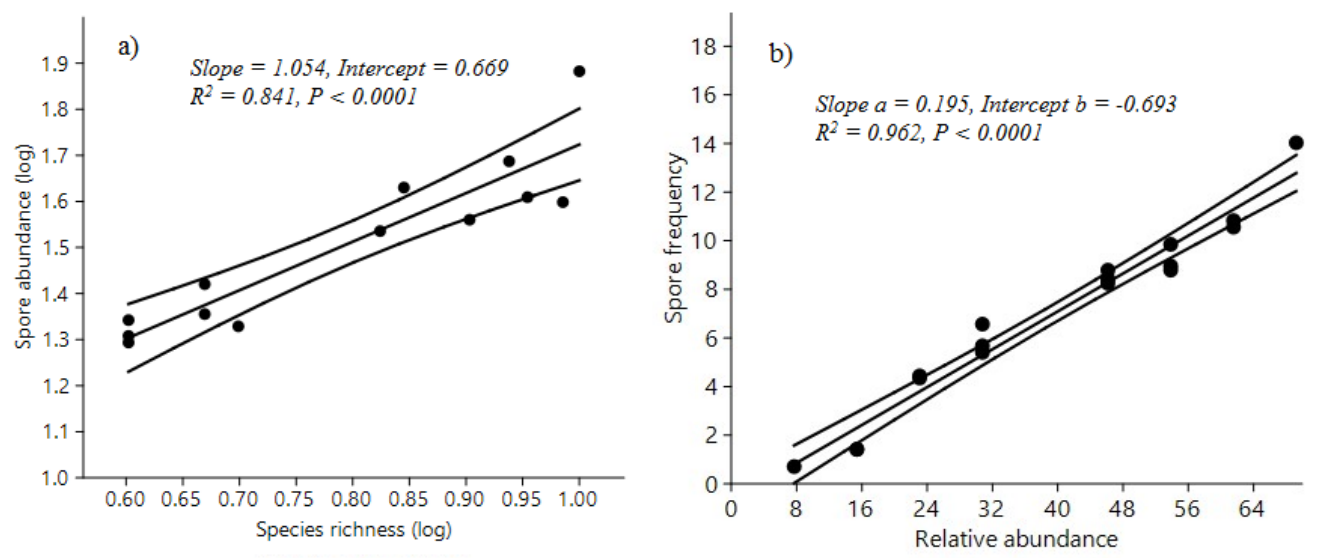

Fig. S1. Relationship between species richness (log) and abundance (log) of arbuscular mycorrhizal (AM) spores (a) and relative abundance and frequency of AM fungal spores (b) among different varieties of cassava.

a)

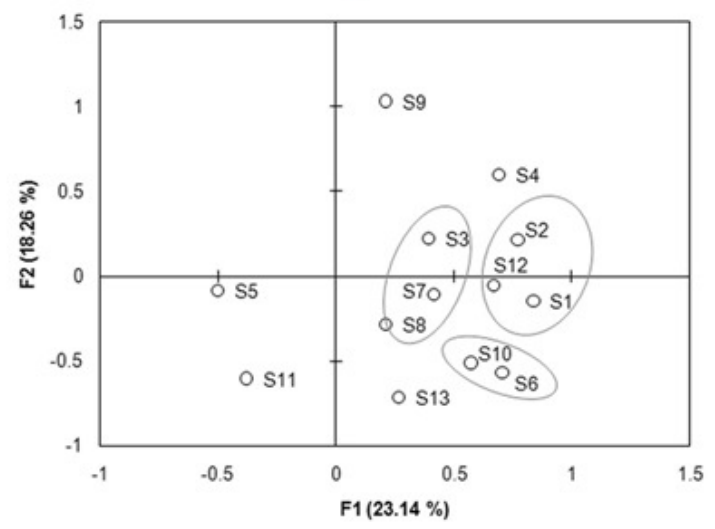

b)

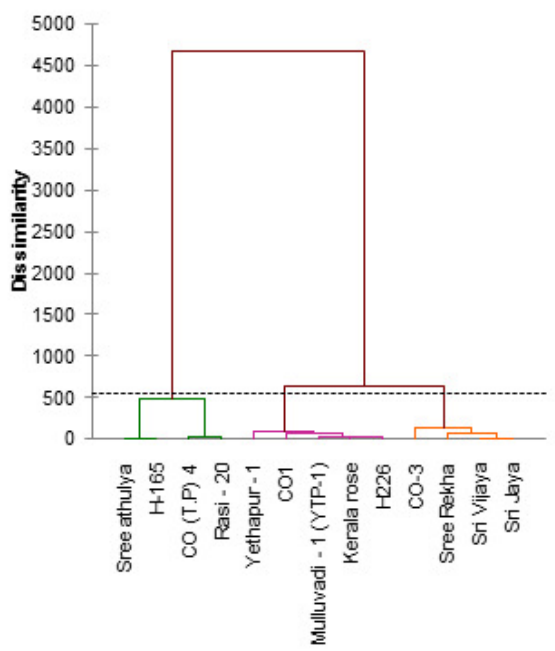

Fig. S2. (a) Principle component analysis of cassava varieties and (b) cluster analysis (CA) on simiarlity relationship on 13 varieties on cassava $(\mathrm{F} 1=23.14 \%$ and $\mathrm{F} 2=18.26)$; The order of cassava variety names $(\mathrm{S} 1-\mathrm{S} 13)$ follow rhizospheric soil samples (Table S5). 
Table S7. Spore numbers of arbuscular mycorrhizal (AM) fungal species, their relative abundance and frequency in different cassava varieties.

\begin{tabular}{|c|c|c|c|c|c|c|c|c|c|c|c|c|c|c|c|}
\hline \multicolumn{14}{|c|}{ Varieties\# (Spore number per 100g soil) } & \multirow[b]{2}{*}{ Frequency } & \multirow{2}{*}{$\begin{array}{l}\text { Relative } \\
\text { abundance }\end{array}$} \\
\hline $\begin{array}{c}\text { AM fungal species } \\
\text { Diversisporales, Acaulosporaceae }\end{array}$ & 1 & 2 & 3 & 4 & 5 & 6 & 7 & 8 & 9 & 10 & 11 & 12 & 13 & & \\
\hline Acaulospora foveatata Trappe \& Janos & $0.00 \pm 0.00 \mathrm{e}$ & $0.00 \pm 0.00 \mathrm{~d}$ & $0.00 \pm 0.00 \mathrm{c}$ & $0.00 \pm 0.00 \mathrm{~b}$ & $0.00 \pm 0.00 \mathrm{f}$ & $0.00 \pm 0.00 \mathrm{c}$ & $0.00 \pm 0.00 \mathrm{~b}$ & $3.33 \pm 1.20 \mathrm{c}$ & $0.00 \pm 0.00 \mathrm{~d}$ & $6.00 \pm 1.53 \mathrm{abc}$ & $0.00 \pm 0.00 \mathrm{c}$ & $11.00 \pm 1.73 \mathrm{ab}$ & $0.00 \pm 0.00 \mathrm{c}$ & 23.07 & 5.41 \\
\hline Acaulospora mellea Spain \& Schenck & $0.00 \pm 0.00 \mathrm{e}$ & $5.00 \pm 2.08 \mathrm{bc}$ & $0.00 \pm 0.00 \mathrm{c}$ & $0.00 \pm 0.00 \mathrm{~b}$ & $6.67 \pm 0.88 \mathrm{ab}$ & $5.00 \pm 0.58 \mathrm{ab}$ & $3.33 \pm 1.20 \mathrm{a}$ & $0.00 \pm 0.00 \mathrm{~d}$ & $0.00 \pm 0.00 \mathrm{~d}$ & $0.00 \pm 0.00 \mathrm{e}$ & $6.33 \pm 1.20 \mathrm{a}$ & $2.67 \pm 1.20 \mathrm{fg}$ & $4.67 \pm 0.67 \mathrm{~b}$ & 53.85 & 8.96 \\
\hline Acaulospora scrobiculata Trappe & $2.33 \pm 1.33 \mathrm{cde}$ & $6.33 \pm 0.67 \mathrm{~b}$ & $0.00 \pm 0.00 \mathrm{c}$ & $5.67 \pm 1.20 \mathrm{a}$ & $0.00 \pm 0.00 \mathrm{f}$ & $4.33 \pm 0.33 \mathrm{ab}$ & $5.33 \pm 1.86 \mathrm{a}$ & $5.67 \pm 1.20 \mathrm{ab}$ & $0.00 \pm 0.00 \mathrm{~d}$ & $6.00 \pm 1.53 \mathrm{abc}$ & $0.00 \pm 0.00 \mathrm{c}$ & $9.67 \pm 0.88 \mathrm{abc}$ & $7.33 \pm 1.20 \mathrm{a}$ & 69.23 & 14.03 \\
\hline Acaulospora sp. & $2.33 \pm 0.88 \mathrm{cde}$ & $6.00 \pm 1.15 \mathrm{~b}$ & $0.00 \pm 0.00 \mathrm{c}$ & $0.00 \pm 0.00 \mathrm{~b}$ & $0.00 \pm 0.00 \mathrm{f}$ & $6.67 \pm 0.88 \mathrm{a}$ & $0.00 \pm 0.00 \mathrm{~b}$ & $0.00 \pm 0.00 \mathrm{~d}$ & $0.00 \pm 0.00 \mathrm{~d}$ & $2.67 \pm 0.67 \mathrm{de}$ & $0.00 \pm 0.00 \mathrm{c}$ & $8.67 \pm 0.33 \mathrm{bcd}$ & $5.33 \pm 0.88 \mathrm{ab}$ & 46.15 & 8.43 \\
\hline $\begin{array}{l}\text { Claroideoglomus etunicatum (W.N. Becker \& } \\
\text { Gerd.) }\end{array}$ & $0.00 \pm 0.00 \mathrm{e}$ & $0.00 \pm 0.00 \mathrm{~d}$ & $0.00 \pm 0.00 \mathrm{c}$ & $0.00 \pm 0.00 \mathrm{~b}$ & $0.00 \pm 0.00 \mathrm{f}$ & $0.00 \pm 0.00 \mathrm{c}$ & $0.00 \pm 0.00 \mathrm{~b}$ & $0.00 \pm 0.00 \mathrm{~d}$ & $5.33 \pm 0.88 \mathrm{~b}$ & $0.00 \pm 0.00 \mathrm{e}$ & $0.00 \pm 0.00 \mathrm{c}$ & $0.00 \pm 0.00 \mathrm{~g}$ & $0.00 \pm 0.00 \mathrm{c}$ & 15.38 & 5.68 \\
\hline $\begin{array}{l}\text { Funneliformis geosporum (T.H. Nicol. \& Gerd.) } \\
\text { C. Walker \& A. Schüßler, }\end{array}$ & $\begin{array}{l}4.00 \pm 1.15 \\
\text { bed }\end{array}$ & $0.00 \pm 0.00 \mathrm{~d}$ & $0.00 \pm 0.00 \mathrm{c}$ & $0.00 \pm 0.00 \mathrm{~b}$ & $5.33 \pm 0.88 \mathrm{bc}$ & $4.00 \pm 1.73 \mathrm{~b}$ & $0.00 \pm 0.00 \mathrm{~b}$ & $0.00 \pm 0.00 \mathrm{~d}$ & $0.00 \pm 0.00 \mathrm{~d}$ & $3.00 \pm 1.53 \mathrm{cde}$ & $0.00 \pm 0.00 \mathrm{c}$ & $0.00 \pm 0.00 \mathrm{~g}$ & $0.00 \pm 0.00 \mathrm{c}$ & 30.77 & 9.85 \\
\hline $\begin{array}{c}\text { Funneliformis mosseae (T.H. Nicolson \& } \\
\text { Gerd.) } \\
\text { C. Walker \& A. Schüßler, }\end{array}$ & $8.00 \pm 1.00 \mathrm{a}$ & $3.33 \pm 1.20 \mathrm{c}$ & $6.33 \pm 0.88 \mathrm{a}$ & $4.00 \pm 1.73 \mathrm{a}$ & $0.00 \pm 0.00 \mathrm{f}$ & $0.00 \pm 0.00 \mathrm{c}$ & $3.33 \pm 1.20 \mathrm{a}$ & $0.00 \pm 0.00 \mathrm{~d}$ & $3.33 \pm 1.20 \mathrm{c}$ & $0.00 \pm 0.00 \mathrm{e}$ & $0.00 \pm 0.00 \mathrm{c}$ & $12.33 \pm 2.40 \mathrm{a}$ & $0.00 \pm 0.00 \mathrm{c}$ & 53.85 & 8.79 \\
\hline \multicolumn{16}{|l|}{ Gigasporaceae } \\
\hline Gigaspora decipiens Hall \& Abbott & $0.00 \pm 0.00 \mathrm{e}$ & $0.00 \pm 0.00 \mathrm{~d}$ & $0.00 \pm 0.00 \mathrm{c}$ & $0.00 \pm 0.00 \mathrm{~b}$ & $0.00 \pm 0.00 \mathrm{f}$ & $0.00 \pm 0.00 \mathrm{c}$ & $0.00 \pm 0.00 \mathrm{~b}$ & $0.00 \pm 0.00 \mathrm{~d}$ & $0.00 \pm 0.00 \mathrm{~d}$ & $7.33 \pm 1.20 \mathrm{ab}$ & $7.00 \pm 1.00 \mathrm{a}$ & $0.00 \pm 0.00 \mathrm{~g}$ & $7.00 \pm 0.58 \mathrm{a}$ & 23.07 & 1.42 \\
\hline $\begin{array}{c}\text { Gigaspora gigantea Nicol. \& Gerd. (Gerd. \& } \\
\text { Trappe) }\end{array}$ & $5.33 \pm 0.88 \mathrm{~b}$ & $2.67 \pm 1.20 \mathrm{~cd}$ & $3.33 \pm 1.76 \mathrm{~b}$ & $4.33 \pm 1.20 \mathrm{a}$ & $0.00 \pm 0.00 \mathrm{f}$ & $4.67 \pm 0.33 \mathrm{ab}$ & $0.00 \pm 0.00 \mathrm{~b}$ & $0.00 \pm 0.00 \mathrm{~d}$ & $5.67 \pm 1.20 \mathrm{~b}$ & $4.67 \pm 1.76 \mathrm{bcd}$ & $0.00 \pm 0.00 \mathrm{c}$ & $6.33 \pm 0.88 \mathrm{cde}$ & $0.00 \pm 0.00 \mathrm{c}$ & 61.54 & 4.35 \\
\hline $\begin{array}{l}\text { Scutellospora calospora (Nicol. \& Gerd.) } \\
\text { Walker \& Sanders }\end{array}$ & $5.00 \pm 0.58 \mathrm{bc}$ & $3.00 \pm 1.00 \mathrm{c}$ & $0.00 \pm 0.00 \mathrm{c}$ & $5.67 \pm 0.67 \mathrm{a}$ & $0.00 \pm 0.00 \mathrm{f}$ & $4.33 \pm 1.20 \mathrm{ab}$ & $0.00 \pm 0.00 \mathrm{~b}$ & $0.00 \pm 0.00 \mathrm{~d}$ & $0.00 \pm 0.00 \mathrm{~d}$ & $8.67 \pm 1.20 \mathrm{a}$ & $0.00 \pm 0.00 \mathrm{c}$ & $0.00 \pm 0.00 \mathrm{~g}$ & $6.33 \pm 1.45 \mathrm{ab}$ & 46.15 & 8.79 \\
\hline \multicolumn{16}{|l|}{ Glomerales } \\
\hline \multicolumn{16}{|l|}{ Glomeraceae } \\
\hline $\begin{array}{l}\text { Glomus aggregatum Schenck\& Smith } \\
\text { emend. Koske. }\end{array}$ & $2.67 \pm 1.33 \mathrm{~b}-\mathrm{e}$ & $0.00 \pm 0.00 \mathrm{~d}$ & $4.67 \pm 0.33 \mathrm{ab}$ & $0.00 \pm 0.00 \mathrm{~b}$ & $2.33 \pm 1.45 \mathrm{e}$ & $4.00 \pm 1.73 \mathrm{~b}$ & $0.00 \pm 0.00 \mathrm{~b}$ & $4.00 \pm 1.73 \mathrm{bc}$ & $0.00 \pm 0.00 \mathrm{~d}$ & $0.00 \pm 0.00 \mathrm{e}$ & $8.00 \pm 2.08 \mathrm{a}$ & $7.33 \pm 1.76 \mathrm{cde}$ & $0.00 \pm 0.00 \mathrm{c}$ & 53.85 & 1.42 \\
\hline $\begin{array}{l}\text { Glomus hyderabadensis Swarupa, Kunwar, } \\
\text { Prasad \& Manohar. }\end{array}$ & $0.00 \pm 0.00 \mathrm{e}$ & $0.00 \pm 0.00 \mathrm{~d}$ & $0.00 \pm 0.00 \mathrm{c}$ & $0.00 \pm 0.00 \mathrm{~b}$ & $4.00 \pm 0.58 \mathrm{cde}$ & $0.00 \pm 0.00 \mathrm{c}$ & $0.00 \pm 0.00 \mathrm{~b}$ & $0.00 \pm 0.00 \mathrm{~d}$ & $0.00 \pm 0.00 \mathrm{~d}$ & $0.00 \pm 0.00 \mathrm{e}$ & $1.33 \pm 0.88 \mathrm{c}$ & $0.00 \pm 0.00 \mathrm{~g}$ & $0.00 \pm 0.00 \mathrm{c}$ & 15.38 & 8.25 \\
\hline Glomus macrocarpum Tul. \& Tul. & $\begin{array}{l}3.00 \pm 1.00 \\
\text { bcd }\end{array}$ & $0.00 \pm 0.00 \mathrm{~d}$ & $3.33 \pm 0.88 \mathrm{~b}$ & $0.00 \pm 0.00 \mathrm{~b}$ & $0.00 \pm 0.00 \mathrm{f}$ & $3.33 \pm 1.20 \mathrm{~b}$ & $4.00 \pm 1.73 \mathrm{a}$ & $0.00 \pm 0.00 \mathrm{~d}$ & $0.00 \pm 0.00 \mathrm{~d}$ & $3.33 \pm 1.20 \mathrm{~cd}$ & $3.67 \pm 1.45 \mathrm{~b}$ & $5.00 \pm 0.58 \mathrm{ef}$ & $5.33 \pm 1.67 \mathrm{ab}$ & 61.54 & 10.56 \\
\hline $\begin{array}{l}\text { Glomus microaggregatum Koske, } \\
\text { Gemma \& Olexia }\end{array}$ & $5.33 \pm 1.67 \mathrm{~b}$ & $9.33 \pm 0.67 \mathrm{a}$ & $0.00 \pm 0.00 \mathrm{c}$ & $0.00 \pm 0.00 \mathrm{~b}$ & $3.00 \pm 1.00 \mathrm{de}$ & $0.00 \pm 0.00 \mathrm{c}$ & $0.00 \pm 0.00 \mathrm{~b}$ & $7.33 \pm 1.20 \mathrm{a}$ & $0.00 \pm 0.00 \mathrm{~d}$ & $7.00 \pm 1.15 \mathrm{ab}$ & $0.00 \pm 0.00 \mathrm{c}$ & $7.67 \pm 1.33 \mathrm{cde}$ & $0.00 \pm 0.00 \mathrm{c}$ & 46.15 & 10.83 \\
\hline Glomus sp. & $1.67 \pm 0.67 \mathrm{de}$ & $0.00 \pm 000 \mathrm{~d}$ & $5.00 \pm 1.15 \mathrm{ab}$ & $0.00 \pm 0.00 \mathrm{~b}$ & $4.67 \pm 0.67 \mathrm{~cd}$ & $0.00 \pm 0.00 \mathrm{c}$ & $5.33 \pm 0.88 \mathrm{a}$ & $0.00 \pm 0.00 \mathrm{~d}$ & $0.00 \pm 0.00 \mathrm{~d}$ & $0.00 \pm 0.00 \mathrm{e}$ & $0.00 \pm 0.00 \mathrm{c}$ & $0.00 \pm 0.00 \mathrm{~g}$ & $0.00 \pm 0.00 \mathrm{c}$ & 30.77 & 4.44 \\
\hline Sclerocystis rubiformis Gerd. \& Trappe. & $0.00 \pm 0.00 \mathrm{e}$ & $3.00 \pm 1.00 \mathrm{c}$ & $0.00 \pm 0.00 \mathrm{c}$ & $0.00 \pm 0.00 \mathrm{~b}$ & $8.33 \pm 0.67 \mathrm{a}$ & $0.00 \pm 0.00 \mathrm{c}$ & $0.00 \pm 0.00 \mathrm{~b}$ & $0.00 \pm 0.00 \mathrm{~d}$ & $7.67 \pm 1.45 \mathrm{a}$ & $0.00 \pm 0.00 \mathrm{e}$ & $0.00 \pm 0.00 \mathrm{c}$ & $5.67 \pm 1.45 \mathrm{def}$ & $0.00 \pm 0.00 \mathrm{c}$ & 30.77 & 6.57 \\
\hline $\begin{array}{l}\text { Septoglomus viscosum (T.H. Nicolson) } \\
\text { C. Walker, D. Redecker, D. Stille \& A. } \\
\text { Schüßler }\end{array}$ & $0.00 \pm 0.00 \mathrm{e}$ & $0.00 \pm 0.00 \mathrm{~d}$ & $0.00 \pm 0.00 \mathrm{c}$ & $0.00 \pm 0.00 \mathrm{~b}$ & $0.00 \pm 0.00 \mathrm{f}$ & $0.00 \pm 0.00 \mathrm{c}$ & $0.00 \pm 0.00 \mathrm{~b}$ & $0.00 \pm 0.00 \mathrm{~d}$ & $0.00 \pm 0.00 \mathrm{~d}$ & $0.00 \pm 0.00 \mathrm{e}$ & $0.00 \pm 0.00 \mathrm{c}$ & $0.00 \pm 0.00 \mathrm{~g}$ & $6.67 \pm 0.88 \mathrm{ab}$ & 7.69 & 0.71 \\
\hline$F(16,50)$ & $8.775^{\cdots \prime}$ & $12.678^{\cdots \prime}$ & 13.716 & $12.792 \cdots$ & $22.5922^{\prime \prime}$ & $9.795{ }^{\prime \prime}$ & $7.181^{\prime \prime}$ & $12.85{ }^{\prime \prime}$ & $18.75^{\prime \prime}$ & $10.45^{\prime \prime}$ & $14.02 \cdots$ & 17.46 & $19.48 \cdots$ & -. & -. \\
\hline
\end{tabular}

\#Varieties 1-13, Yethapur - 1, CO (T.P) 4, Sri Vijaya, CO-3, Kerala rose, Sree Athulya, Rasi - 20, Sri Jaya, Sree Rekha, Mulluvadi - 1, H-165, CO1, H226

Mean \pm SE followed by same letter $(s)$ are not significantly $(p>0.05)$ different according to DMRT 